\title{
Natural Antisense Transcripts: Molecular Mechanisms and Implications in Breast Cancers
}

\author{
Guillaume Latgé ${ }^{1}$, Christophe Poulet ${ }^{1}$, Vincent Bours ${ }^{1,2}$, Claire Josse ${ }^{1,3,4}$ (D) and \\ Guy Jerusalem ${ }^{3,4, *}$ \\ 1 Laboratory of Human Genetics, GIGA-Institute, University of Liège, 4500 Liège, Belgium; \\ g.latge@doct.ulg.ac.be (G.L.); christophe.poulet@ulg.ac.be (C.P.); vbours@ulg.ac.be (V.B.); \\ c.josse@chu.ulg.ac.be (C.J.) \\ 2 Center of Genetics, University Hospital (CHU), 4500 Liège, Belgium \\ 3 Department of Medical Oncology, University Hospital (CHU), 4500 Liège, Belgium \\ 4 Laboratory of Medical Oncology, GIGA-Institute, University of Liège, 4500 Liège, Belgium \\ * Correspondence: g.jerusalem@chu.ulg.ac.be; Tel.: +32-4-366-76-64
}

Received: 13 October 2017; Accepted: 29 December 2017; Published: 2 January 2018

\begin{abstract}
Natural antisense transcripts are RNA sequences that can be transcribed from both DNA strands at the same locus but in the opposite direction from the gene transcript. Because strand-specific high-throughput sequencing of the antisense transcriptome has only been available for less than a decade, many natural antisense transcripts were first described as long non-coding RNAs. Although the precise biological roles of natural antisense transcripts are not known yet, an increasing number of studies report their implication in gene expression regulation. Their expression levels are altered in many physiological and pathological conditions, including breast cancers. Among the potential clinical utilities of the natural antisense transcripts, the non-coding I coding transcript pairs are of high interest for treatment. Indeed, these pairs can be targeted by antisense oligonucleotides to specifically tune the expression of the coding-gene. Here, we describe the current knowledge about natural antisense transcripts, their varying molecular mechanisms as gene expression regulators, and their potential as prognostic or predictive biomarkers in breast cancers.
\end{abstract}

Keywords: non-coding RNA; IncRNA; natural antisense transcript; natural antisense transcripts; breast cancer; next generation sequencing; gene expression regulation

\section{Introduction}

After an international effort, the scientific community has revealed that up to $90 \%$ of the human genome is transcribed. Thanks to the FANTOM project (functional annotation of the mammalian genome, available online: http:/ / fantom.gsc.riken.jp/), started in 2000 with the mouse genome [1,2], which was quickly followed by the human genome in 2003 by the ENCODE project (encyclopedia of DNA elements, available online: https://www.encodeproject.org/) [3,4], we know that $98 \%$ of the human genome is composed of non-coding (nc) sequences, previously considered "Junk DNA" due to their heterogeneity, low expression levels, and unknown functions [5-11]. This huge part of the transcriptome could therefore play a role in protein-coding $(\mathrm{pc})$ RNA expression regulation. Databases specialized in genome annotation, such as the GENCODE project (encyclopædia of genes and gene variants, available online: http:/ / www.gencodegenes.org/) [12,13], specialized in ncRNA, such as the NONCODE (integrated knowledge database dedicated to ncRNAs, especially lncRNAs, available online: http:/ / www.noncode.org/) and RNAcentral projects (the non-coding RNA sequence database, available online: http:/ / rnacentral.org/) [14,15], or specialized in human long non-coding RNAs (lncRNAs), such as the LNCipedia project (a comprehensive compendium of human long 
non-coding RNAs, available online: https:/ /ncipedia.org/) [16], are now illustrating this new vision of the transcriptome.

Non-coding RNAs are classified according to their transcript length. With few exceptions, a 200-nt arbitrary threshold is used to separate short and long ncRNAs [17]. The long non-coding RNAs (lncRNAs) make up the largest portion of ncRNAs. With approximatively $98 \%$ of the genome containing non-coding regions and only $1.1 \%$ containing exons, it is obvious that many lncRNAs do not overlap exons. IncRNAs are classified according to their original genomic location and their context when compared to a protein-coding gene (pcGene) [18-20]. Figure 1 depicts the five current categories of IncRNAs, named intergenic, intronic, bidirectional (or divergent), sense and antisense. Sense and antisense lncRNAs are defined according to the nearest $p c$ Gene position. Both can overlap, partially or entirely, one or more exons of a pcGene [2]. Bidirectional lncRNA transcription starts close to a pcGene (less than $1 \mathrm{~kb}$ from the $p c G e n e$ transcription start site) and proceeds in the opposite direction as $p c G e n e$ transcription. Intronic lncRNAs are transcribed entirely from introns, and do not overlap with any exon [20-22]. Those in intergenic regions are named long intergenic non-coding RNAs (lincRNAs), and their transcription can occur in both directions $[23,24]$. Some ncRNA classification exceptions are also worth noting. A few lncRNAs, such as BC1 or snaR, contain less than or close to $200 \mathrm{nt}$, but they are classified as lncRNAs in the lncRNAdb database (the reference database for functional long noncoding RNAs, available online: http:/ /ncrnadb.org/) [25]. Other lncRNAs can reach lengths of 1 Mbase and are thus called very long intergenic RNA (vlincRNA) [26].

\section{Long non-coding RNAs}

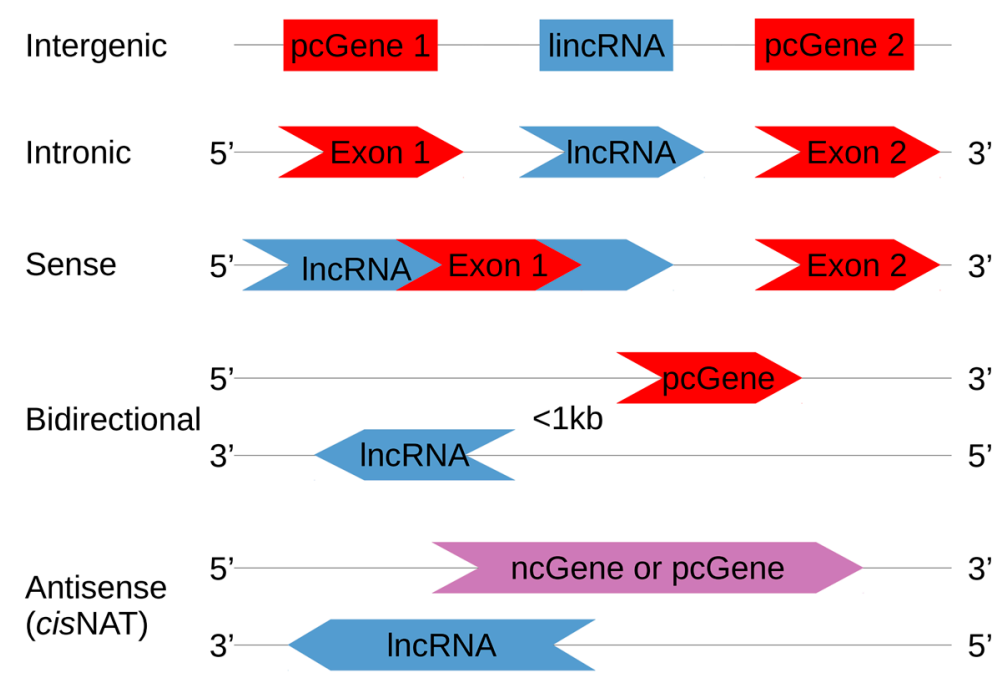

Figure 1. IncRNA classification according to their orientation and position in the genome. lincRNAs are located between two $p c$ Genes, regardless of their orientation. Intronic lncRNAs are entirely encoded in $p c$ Gene introns, while sense lncRNAs overlap pcGene exons. Bidirectional lncRNA transcription starts less than $1 \mathrm{~kb}$ from a $p c G e n e$ transcription start site and goes in its opposite direction. Cis-NATs (natural antisense transcript) are RNA sequences that are transcribed from the two strands of the same genomic locus, in the antisense direction. NAT pairs can be protein-coding sequences ( $\mathrm{pc}$, red colored) or non-coding sequences (nc, blue colored), forming $\mathrm{nc}|\mathrm{pc}, \mathrm{nc}| \mathrm{nc}$ or $\mathrm{pc} \mid \mathrm{pc}$ pairs. NAT pairs that are $\mathrm{nc}$ l pc or nc I nc sequences only belong to the lncRNA classification (purple colored sequences are pc or nc).

IncRNAs are defined as endogenous cellular RNAs without a significant ORF (open reading frame) [27-29]. However, some ncRNAs containing an ORF smaller than 100 amino-acids may be classified as lncRNAs [27]. The known biological roles of lncRNAs are very heterogeneous and cover various molecular and cellular functions such as pcGene regulation [30], stem cell pluripotency and differentiation [31], allelic expression [32], cell cycle control [33], apoptosis and senescence [34], 
heat shock response [35], and control of chromatin modifications [36]. It is worth noting that lncRNAs are found in all tissues and show pronounced tissue-specific expression. Their cellular location may vary, probably reflecting their function $[20,37,38]$. There is a structural similarity between lncRNAs and mRNAs, in the sense that they may be multi-exonic, $5^{\prime}$ capped, $3^{\prime}$ polyadenylated, and spliced [23]. RNA polymerase II (RNA Pol II) is responsible for the transcription of most of the lncRNAs, and their expression is under the control of promoters and enhancers, that can be induced by external stimuli [23].

\section{Generic Definition of NATs}

Natural antisense transcripts (NATs) are coding or non-coding RNA sequences that are complementary to and overlap with either protein-coding or non-coding transcripts [39]. As $98 \%$ of the transcriptome is non-coding, the vast majority of paired transcripts are composed of ncl nc or $\mathrm{ncl}$ pc pairs. Therefore, NATs are defined in regard to the relative genomic position from their paired transcript origins, in cis or in trans. Cis-NAT pairs are transcribed from the opposite strand of the same genomic locus and display perfect RNA I RNA sequence complementarity with the opposite strand transcript (if no RNA modifications, such as RNA editing, occur). Trans-NAT pairs are transcribed from different genomic loci, and the two RNA molecules may hybridize to each other with imperfect RNA | RNA sequence complementarity [40,41].

Because whole genome sequencing of the antisense transcription has only been available for less than a decade, many NATs were described as IncRNAs without information about the co-existence of other transcripts from the same genomic origin. This convergence between NAT and lncRNA classifications may thus lead to some confusion in the literature and will probably disappear with the increasing knowledge in the antisense transcription field.

\section{NAT: Structure, Localization, and Expression Regulation}

Like IncRNAs and mRNAs, NATs may be capped and poly-adenylated transcripts that are maturated to excise introns. NAT expression is also controlled by promoters and enhancers. In addition, many examples of bidirectional promoters that control transcript expression originating from both strands are described in the literature [42,43]. In this case, several transcription factors, such as GABPA or E2F1, are preferentially implicated [44-46]. NATs may originate from cryptic promoters that are then inserted within the intronic regions of a gene or close to the transcription start site of neighboring genes $[43,47,48]$.

NATs accumulate preferentially in the nucleus, associating with chromatin, unlike coding mRNAs which accumulate in the cytoplasm. NATs are also found in other cellular compartments, such as mitochondria, and have been reported to accumulate at polysomes [3,18,49]. Moreover, NAT expression is closely linked with the activity of their sense or neighboring genes [43].

\section{NAT: Role, Function and Mechanism of Action}

The biological significance of NATs remains under scientific investigation with major key questions yet to be answered. Specific $p c G e n e$ regulation by their corresponding overlapping ncNATs has been reported. Our team and others have shown that up to $50 \%$ of the $p c G e n e s$ also express ncNATs $[2,39,50]$ and that transcript levels of nclpc pairs are often tightly correlated $[39,46,50]$. Altogether, this suggests that NATs could be implicated in a new level of gene expression regulation [5,51].

Both transcriptional and post-transcriptional regulations of expression have also been explained as the result of the creation of natural sense and antisense transcript pairs. The regulatory processes implicated can be more or less complex, ranging from simple transcriptional interference to modulation of chromatin changes or the formation of double-stranded RNA (dsRNA). The latter leads to RNA masking, RNA interference or RNA editing [52].

Several examples of $p c G e n e$ expression regulation by their NATs are described hereafter to illustrate the different molecular mechanisms of action. 


\subsection{Action in Cis or Trans}

While NATs are more likely to handle regulation of other genes in cis, they may also tune gene expression elsewhere in the genome by trans regulation. Based on the definition of overlapping genes from Makalowska et al., cis-NATs are here classified according to the relative position of the DNA coding sequence of the RNA transcripts [53]. Three categories can thus be described and are depicted in Figure 2: (1) "head-to-head", where sense and antisense transcripts overlap on their 5' ends; (2) "tail-to-tail", where sense and antisense transcripts overlap on their $3^{\prime}$ ends; and (3) "embedded overlap" (also called "full overlap"), where one of the entire transcript overlaps the other.

\section{Natural antisense transcripts}

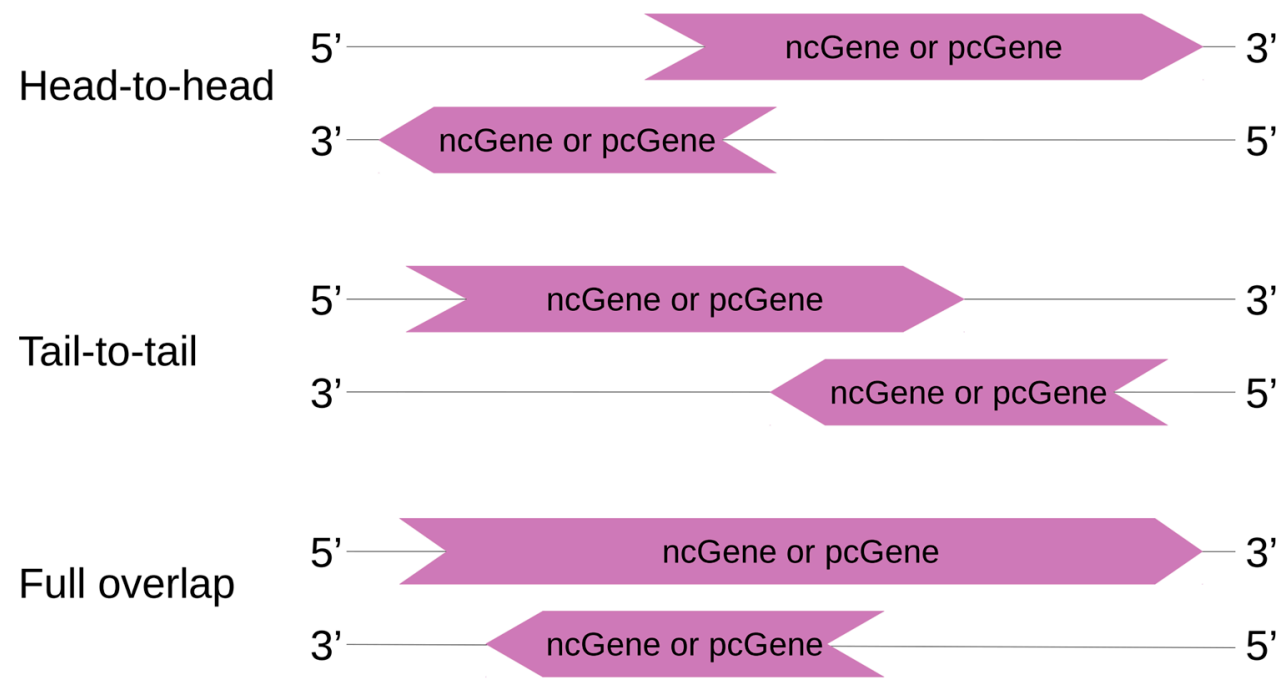

Figure 2. cis-NAT classification. cisNAT pairs can be protein coding sequences (pc) or non-coding sequences (nc), forming $\mathrm{nc} \mid \mathrm{pc}$, nc $\mid \mathrm{nc}$ or $\mathrm{pc} \mid \mathrm{pc}$ pairs. In head-to-head orientation, sense and antisense transcripts overlap on their $5^{\prime}$ ends. Inversely, tail-to-tail describes an overlap of the $3^{\prime}$ ends. In a full overlap (or embedded overlap), one transcript is totally included in the other one.

\subsection{Transcriptional Interference}

Antisense transcription can modulate in cis the sense transcription of the opposite strand, although this effect may not be caused by the pairing of the RNA molecules themselves. The proximity of the two transcriptional events, sense and antisense, leads to a downregulation of both transcripts [54]. Transcriptional interference can occur during the initiation or elongation phases of transcription. In the initiation phase, promoters of head-to-head NATs are competing for the use of RNA Pol II and common regulatory elements (Figure 3A). In the elongation phase, interference can occur after the following events: a collision between RNA Pol II complexes, leading to a machinery blockage (Figure 3B); a promoter occlusion by RNA Pol II during the antisense transcript elongation (Figure 3C); or an RNA Pol II dislodgement by the RNA Pol II standing on the opposite strand, when the first one was too slow to start (Figure 3D) [54]. It is worth noting that the transcriptional interference investigation field is still young and that formal proof of gene expression regulation by this mechanism was only recently reported [55]. Nevertheless, a negative correlation between sense and antisense transcript levels are less frequently observed than a positive correlation or no correlation. This suggests that only a minority of NATs could be involved in transcriptional interference processes [50,56-59]. 


\section{A Promoter Competition}

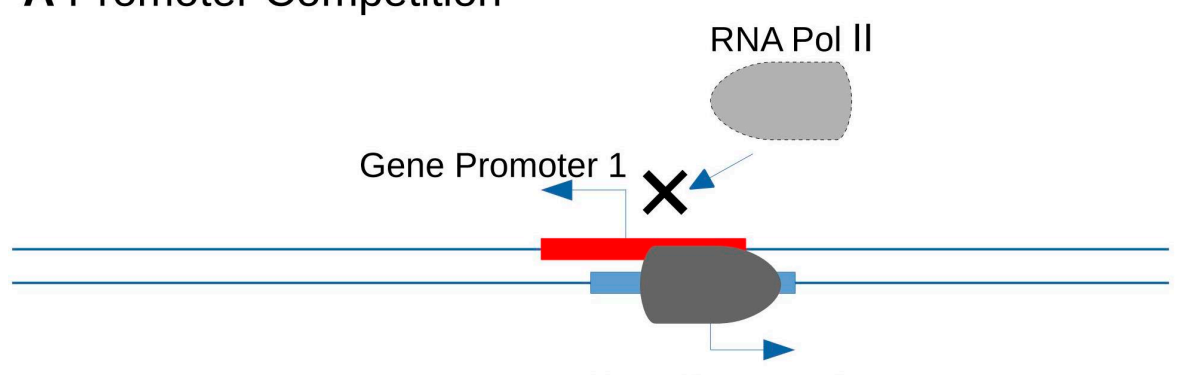

Gene Promoter 2

\section{B Collision}

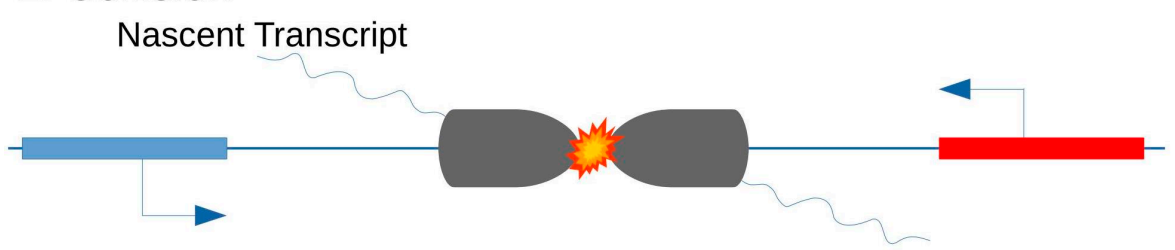

\section{Promoter occlusion}

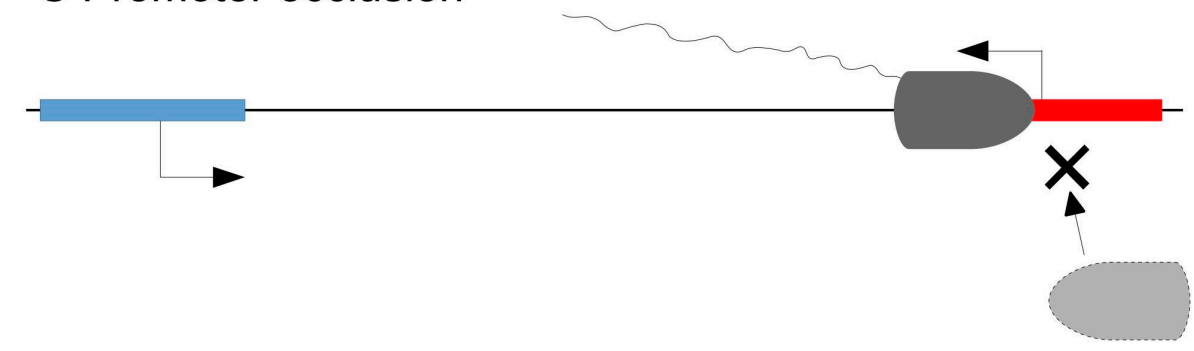

D RNA Pol II dislodgement

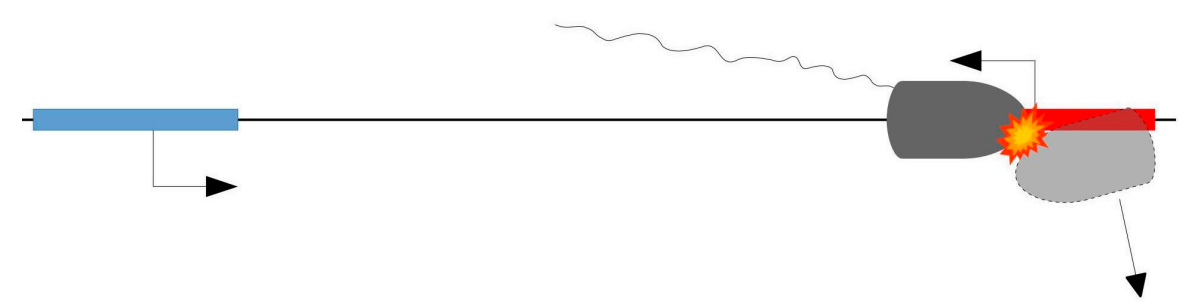

Figure 3. Transcriptional Interference: $(\mathbf{A})$ in the initiation phase, promoters of head-to-head NATs are competing for the use of RNA Pol II and common regulatory elements; (B) in the elongation phase, interference can occur after the following events: a collision between RNA Pol II complexes, leading to a machinery blockage; (C) a promoter occlusion by RNA Pol II during the antisense transcript; and (D) a RNA Pol II dislodgement by the RNA Pol II standing on the opposite strand, when the first one was too slow to start. Promoters of protein coding sequences are represented in red, and promoters of non-coding sequences in blue. RNA pol II enzyme is represented in dark grey when able to transcribe the sequence, and light grey when its binding and thus activity, is prevented.

Despite difficulties in discriminating transcription interference from gene expression regulation by RNA transcripts, Stojic et al. [55] have demonstrated such a mechanism by screening an siRNA library. Whereas nearly all siRNAs dampen GNG12-AS1 (a non-coding natural antisense transcript of the tumor suppressor coding gene DIRAS3) post-transcriptionally, siRNA targeting exon 1 of GNG12-AS1 downregulates its transcription by recruiting Argonaute 2 and inhibiting RNA polymerase II binding. In this case, the active transcription of GNG12-AS1 causes the transcriptional silencing of DIRAS3, leading to increased cell proliferation. 


\subsection{Chromatin Modification}

ncNATs may regulate the expression levels of the sense pcGenes by regulating chromatin modifications. Such epigenetic modifications encompass DNA methylations of cytosine in CpG islands and histone modifications by methylation or acetylation of lysine residues. NATs and, more widely, ncRNAs, are thought to affect DNA methylation by interacting with various types of proteins involved in histone modification or chromatin remodeling such as, in particular, the polycomb repressive complex 2 (PRC2) [60]. A current hypothesis considers that nascent NATs guide PRC2 to specific-target sites on the chromatin. The tethering would occur by pairing the nascent NAT with DNA or mRNA sequences, during or after NAT transcription (Figure 4A) [61].
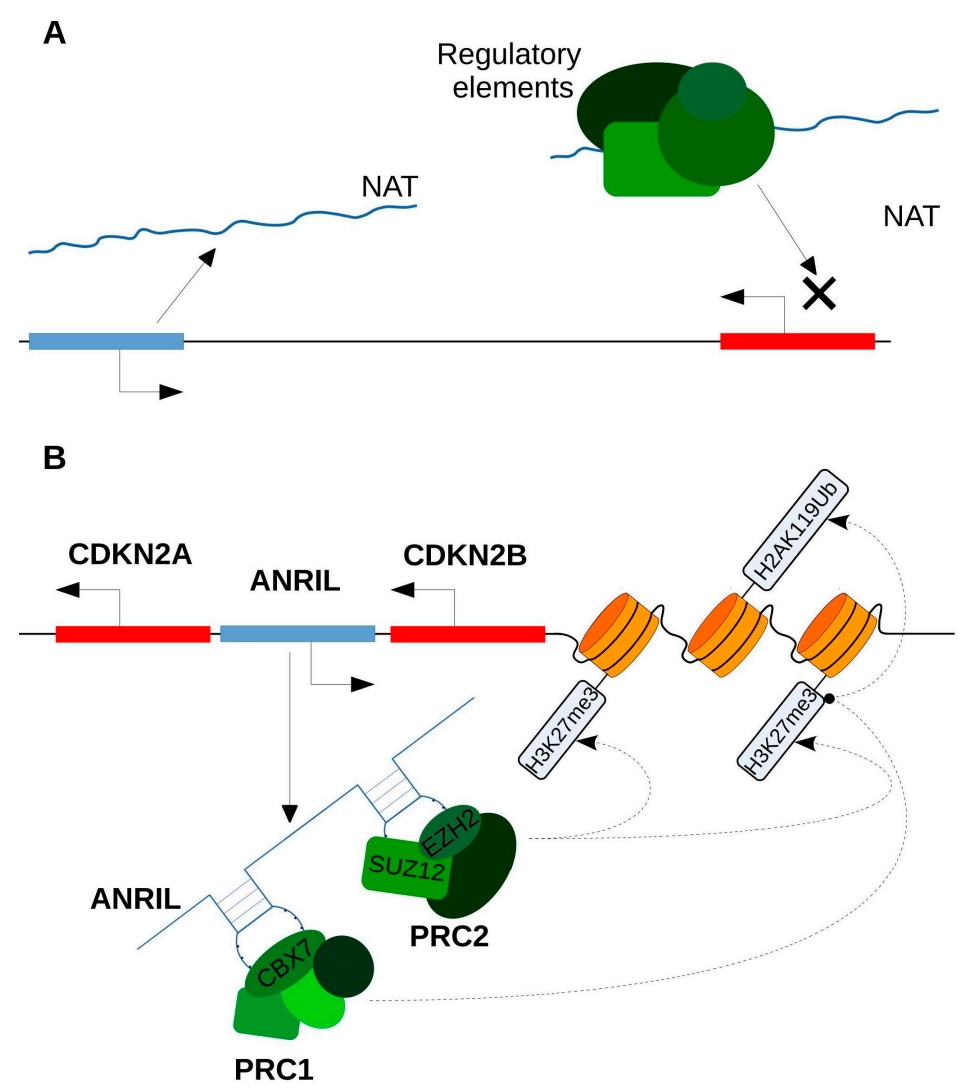

Figure 4. ncNATs (non-coding natural antisense transcripts) may regulate the expression levels of the sense pcGenes (protein coding genes) by regulating chromatin modifications by the following. (A) A decoy mechanism: The NAT binds a protein complex that can trigger chromatin modifications and prevents, by competition, this complex from binding the sense transcript. This complex can also prevent the interaction of the sense gene with RNA Pol II (RNA polymerase II); (B) a tethering mechanism, such as ANRIL (antisense non-coding RNA in the INK4 locus): ANRIL recruits PRC2 (polycomb repressive complex) through interaction with SUZ12 (suppressor of zeste 12 homolog) and EZH2 (enhancer of zeste 2 polycomb repressive complex 2 subunit) components and PRC1 by binding CBX7 (chromobox homolog 7). Next, PRC2 silences the INK4 locus expression by inducing H3K27 tri-methylation, and PRC1 maintains a repressive chromatin structure by mono-ubiquitination of H2AK119. Protein coding sequences or promoters are represented in red, and non-coding in blue.

Additionally, a "decoy" mechanism can be described, where the NAT binds a protein complex, such as PRC2, and prevents this complex from binding the sense transcript by competition. This complex can also prevent the interaction of the sense gene with RNA Pol II or the chromatin $[61,62]$.

Here are two examples of lncRNA/NAT that play a role in the tethering of PRC2 with chromatin. The first example is the combined action of ANRIL and PRC1-PCR2 on INK4b-ARF-INK4a gene 
expression and on the chromatin structure of this locus. ANRIL is a cisNAT that is dysregulated in breast cancer. It is located in the INK4b-ARF-INK4a gene cluster, which contains three genes encoding the three tumor-suppressor proteins p15, p14 and p16 [63]. Polycomb repressive complexes 1 and 2 (PRC1 and PRC2) are implicated in epigenetic silencing mechanisms. ANRIL can recruit those complexes to the chromatin of the INK4b-ARF-INK4a locus, recruiting PRC2 through interaction with SUZ12 and EZH2 components, and recruiting PRC1 by binding CBX7 [63-65]. Next, PRC2 silences INK4b-ARF-INK4a gene expression by inducing H3K27 tri-methylation, and PRC1 maintains a repressive chromatin structure by mono-ubiquitination of H2AK119 (Figure 4B) [66].

A second example is HOTAIR, which is implicated and dysregulated in many types of cancer and displays an active and critical role in chromatin dynamics $[67,68]$. Like ANRIL, HOTAIR interacts with PRC2 through its $5^{\prime}$ end to induce H3K27 tri-methylation. In addition, HOTAIR binds to LSD1 (lysine-specific demethylase 1) by its $3^{\prime}$ end, leading to H3K4 demethylation. These combined modifications lead, in trans, to a repressive chromatin structure and thus to the silencing of multiple genes $[68,69]$.

\subsubsection{Double-Stranded RNA/RNA Masking}

NATs can regulate gene expression through the formation of a complex of two overlapping NAT sequences. This double-stranded RNA (dsRNA) molecule thus creates a physical protection against post-transcriptional regulation factors that target the $p c G e n e$. RNA masking will then interfere with splicing or translation machineries. This mechanism will also prevent miRNA binding or RNAse activities, which often target single-stranded RNA and influence their complex stability [52]. Under this condition and in opposition with other mechanisms described above, NAT positively regulates pcGene expression.

In osteocarcinoma, upregulated FGFR3-AS1 forms a tail-to-tail dsRNA with FGFR3, its sense transcript. FGFR3 mRNA is thus protected against RNase activity, leading to an increase in both its mRNA stability and its protein production [70]. Conversely, binding of the MALAT1 3' UTR by its ncNAT TALAM1 allows for RNase P cleavage, leading to $3^{\prime}$ end processing and maturation that is essential for MALAT1 stability and function [71].

While forming dsRNAs, NATs can also interfere with splicing and translation mechanisms. For example, the protein coded from the gene ZEB2 is a transcriptional factor that downregulates E-cadherin and its antisense transcript, ZEB2-AS1. ZEB2 also contains an IRES (internal ribosome entry site) required for its translation. By binding this sequence, ZEB2-AS1 promotes ZEB2 splicing and downregulates its protein expression [72].

\subsubsection{Double-Stranded RNA/RNA A to I Editing}

ADARs (adenosine deaminases that act on RNA) are enzymes responsible for RNA editing by site-specific adenosine deamination. They target dsRNA molecules such as those formed by NAT pairs. After adenosine to inosine (A-to-I) editing, inosines (I) are interpreted as a guanosines (G) during splicing or translation. Such modification may modulate the localization or the stability of the edited transcripts [73,74]. The occurrence frequency of RNA editing by NATs is not yet characterized $[52,75,76]$. Indeed, few NATs display edited sequences, but they may be quickly degraded or retained in the nucleus, thus disappearing from the bulk of the expressed sequences [77].

An example of this A to I editing mechanism has been found in human prostate cancers with the sense/antisense couple of PRUNE2 and PCA3 transcripts. PRUNE2 is a pcGene that has a tumor suppressor role. PCA3 is an NAT that originates from introns, and is fully overlapped by PRUNE2's 6th intron. The dsRNA created by PCA3 and PRUNE2's pre-mRNA forms a complex with ADAR proteins. An A-to-I editing of this dsRNA leads to a downregulation of protein expression and an increase in tumor cell growth [78]. It is important to note that PCA3 was also approved as a specific biomarker for diagnostic tests. 


\subsubsection{Double-Stranded RNA/RNA Interference}

RNA interference is an additional mechanism whereby NATs are implicated in pcGene post-transcriptional regulation [79]. RNA interference is the endogenous siRNA formation from NAT-derived dsRNA. RNA interference is DICER-dependent and is followed by the action of the RNA-induced silencing complex (RISC) [80-82]. NATs may thus serve as precursors in endo-siRNA and miRNA production [83]. NATs form internal hairpins or duplexes with sense RNA, leading to a dsRNA that can be handled and digested by DICER. Short RNA duplexes will then be bound by the RISC complex, where one strand of the RNA duplex is used as a guide for mRNA recognition. This mRNA is then cleaved by the RISC complex, which will decrease the protein expression. Even with scarce evidence of NAT involvement in the RNA interference process, recent transcriptome sequencing studies have shown the widespread occurrence of endo-siRNAs and their regulatory potential during stages of development and differentiation $[82,83]$.

\section{NATs in Breast Cancer}

Numerous studies have highlighted a link between lncRNA/NAT and cancers, especially breast cancers. Most of these transcripts were either highlighted by high-throughput transcriptomic studies that lacked the strand origin, or explored one by one due to their implication in oncogenic pathways. Therefore, many lncRNA listed in Table 1 are generally not described as NAT in the literature. In addition, the expression correlation between the NAT pair transcripts, as well as the ncNAT regulatory role with regard to the paired $p c G e n e$, are often unknown. It is also worth noting that most genomic loci coding for NAT transcript pairs also display numerous alternative transcripts. Therefore, each lncRNA transcript may belong to different classes among NAT pclnc, lincRNA, IncRNA, or NAT nc Inc.

To the best of our knowledge, only three strand-specific whole genome transcriptomic studies were performed on breast cancer samples $[39,46,50]$. The main concordant conclusions were that: (i) pcGene transcription coincides with an antisense ncNAT transcription in 50\% of the cases; (ii) NAT transcripts are 1000 times less abundant than $p c G e n e$ transcripts; and (iii) positive expression correlations between ncNATs and their paired $p c G e n e s$ are approximately six times more frequent than negative correlations. This latest suggests that if ncNATs can affect the expression of their corresponding pcGene, positive regulation of expression should be more frequently observed than repression. However, a comparison of transcript levels between tumors and paired non-malignant adjacent healthy tissues showed that the ncNAT/pcGene transcript balance is disrupted in tumors. Therefore, new positive correlations of NAT/pcGene pairs are created in tumor tissues, while others that were present in the normal tissue decline [50].

The mechanism by which lncRNA/NAT regulates pcGene expression is known in several instances, and two mechanisms are often described in breast cancer. The first is driven by the polycomb repressing complexes (PRC), and the second by microRNAs. Here are three examples of PRC2 involvement in cancer pathways. The NAT ANRASSF1 leads PRC2 binding on the RASSF1 promoter to regulate RASSF1 expression [84]. The INK4b-ARF-INK4A locus coding for the cell cycle associated proteins p14, p15 and p16 is regulated by the NAT ANRIL via PRC2, and in addition, the lncRNA PANDAR recruits PRC1 to also regulate p16 expression [63-65,85]. Similarly, the p53 pathway is regulated at several levels via PCR2 by HOTAIR and MEG3 IncRNAs [86-89]. The importance of gene regulation by PRC2 is well known in breast cancers, as the expression of its targeted genes can be used to predict patient outcomes [90].

As displayed in Table 1, microRNAs are also frequently involved in gene regulation by lncRNA. One particular example is the epithelial to mesenchymal transition (EMT) that is regulated by three lncRNAs, namely, H19, linc-RoR and TP73-AS, which capture multiple microRNAs and prevent their binding to other mRNA targets [91-94]. 
Table 1. Role and therapeutic utility of lncRNAs in breast cancer. lncRNAs implicated in breast cancer pathology are listed and classified in different categories: lincRNA (long intergenic non-coding RNA), bidirectional lncRNA, sense-overlapping lncRNA, sense-intronic lncRNA, and NAT composed of nc I nc or nc I pc transcripts pairs. In the case of nc l pc pairs, the pcGene name is provided. As ncRNAs often display multiple transcript variants, some lncRNAs may belong to multiple categories.

\begin{tabular}{|c|c|c|c|c|c|c|c|}
\hline $\begin{array}{l}\text { IncRNA in } \\
\text { Breast Cancer }\end{array}$ & Access Number & Type & pcGene & $\begin{array}{l}\text { Alteration/Role in } \\
\text { Breast Cancer }\end{array}$ & Mechanism of Action & Therapeutic Utility & Ref. \\
\hline ANRASSF1 & ENSG00000281358 & NAT (nclpc) & RASSF1 & Upregulation/Oncogenic & Binds to PRC2 and silences the tumor suppressor gene RASSF1A. & & [84] \\
\hline ANRIL & ENSG00000240498 & NAT (nc $\mid p c)$ & $\begin{array}{l}\text { CDKN2A, } \\
\text { CDKN2B }\end{array}$ & Upregulation/Oncogenic & $\begin{array}{l}\text { ANRIL is the NAT of CDKN2B gene (p15); binds to components } \\
\text { of PRC1 (CBX7) and PRC2 (SUZ12) to silence the INK4 locus by } \\
\text { epigenetic mechanisms. }\end{array}$ & Overexpressed in a variety of cancers and diseases. & [63-65] \\
\hline LINC00901 & ENSG00000242385 & NAT (nclpc) & LSAMP & $\begin{array}{l}\text { Downregulation/Tumor } \\
\text { suppressor }\end{array}$ & Low expression is associated with low overall survival. & Potential prognostic marker. & [95] \\
\hline BCAR4 & ENSG00000262117 & lincRNA & & Upregulation/Oncogenic & $\begin{array}{l}\text { Interaction with SNIP1 and PNUTS in Hedgehog canonical } \\
\text { pathway leads to a resistance to cancer treatments with } \\
\text { SMO inhibitors. }\end{array}$ & $\begin{array}{l}\text { Responsible for the acquisition of resistance to } \\
\text { treatments and upregulation of non-canonical } \\
\text { hedgehog pathway. }\end{array}$ & {$[96,97]$} \\
\hline BCYRN1 & ENSG00000236824 & NAT (nclnc) & & Upregulation/Oncogenic & BCYRN1 expression is associated with cell proliferation. & $\begin{array}{l}\text { Knockdown BCYRN1 impacts viability of actively } \\
\text { proliferating cells through growth arrest and } \\
\text { apoptosis. Potential therapeutic target for } \\
\text { various cancers. }\end{array}$ & [98] \\
\hline CCAT2 & ENSG00000280997 & NAT (nclnc) & & Upregulation/Oncogenic & $\begin{array}{l}\text { Downregulates p15 through interaction with EZH2. Regulates } \\
\text { TGF- } \beta \text { and Wnt signaling pathways. Promotes cell proliferation, } \\
\text { invasion, tumor growth and metastasis. }\end{array}$ & Potential prognosis biomarker and therapeutic target. & [99-103] \\
\hline CRNDE & ENSG00000245694 & lincRNA & & Upregulation/Oncogenic & $\begin{array}{l}\text { Molecular sponge of miRNA-136 in breast cancer, activating } \\
\text { Wnt } / \beta \text {-catenin. }\end{array}$ & Associated with unfavorable prognosis. & [104] \\
\hline DANCR & ENSG00000226950 & lincRNA & & Upregulation/Oncogenic & Participates in cell proliferation and invasion. & Associated with a worse prognosis in TNBC. & [105] \\
\hline DSCAM-AS1 & ENSG00000235123 & NAT (nc $\mid p c)$ & DSCAM & Upregulation/Oncogenic & $\begin{array}{l}\text { Expression induced by estrogen stimulation. Positive correlation } \\
\text { with genes associated with cancer aggression, tamoxifen } \\
\text { resistance, and metastasis. }\end{array}$ & Biomarker for luminal subtype. & {$[106,107]$} \\
\hline FAM83H-AS1 & ENSG00000282685 & lincRNA & & Upregulation/Oncogenic & Most upregulated in luminal subtype of breast cancer. & Prognostic marker of luminal subtype. & [108] \\
\hline GAS5 & ENSG00000234741 & $\begin{array}{c}\text { NAT } \\
\text { (ncl pc)/bidirectional } \\
\text { lncRNA/lincRNA } \\
\text { (multiple transcripts) } \\
\end{array}$ & ZВTB37 & $\begin{array}{l}\text { Downregulation/Tumor } \\
\text { suppressor }\end{array}$ & $\begin{array}{l}\text { Required for decoy of glucocorticoid receptor (GR), inhibits } \\
\text { transcriptional induction by GR, stops growth and triggers } \\
\text { apoptosis, induces PTEN through miR-103 inhibition. }\end{array}$ & $\begin{array}{l}\text { Responsible for the acquisition of trastuzumab } \\
\text { resistance. Potential circulating biomarker. }\end{array}$ & [109-114] \\
\hline H19 & ENSG00000130600 & lincRNA & & Upregulation/Oncogenic & $\begin{array}{l}\text { Mediates breast cancer cell plasticity, invasion, and proliferation } \\
\text { by sponging several miR (miR-200b/c, let-7b, miR-152), silences } \\
\text { pro-apoptotic gene } B I K \text { through epigenetic modifications, } \\
\text { precursor of miR- } 675 \text { (pro-tumoral and pro-metastatic). }\end{array}$ & $\begin{array}{l}\text { Upregulated in cancer. Potential circulating } \\
\text { biomarker for early screening and prognosis } \\
\text { monitoring in breast cancer. }\end{array}$ & {$[92,115-118]$} \\
\hline HIF1A-AS2 & ENSG00000258667 & $\operatorname{NAT}(\mathrm{nc} \mid \mathrm{pc})$ & HIF1A & Upregulation/Oncogenic & $\begin{array}{l}\text { Involved in cell proliferation and invasion, contributes to } \\
\text { chemotherapy resistance. }\end{array}$ & $\begin{array}{l}\text { In TNBC, biomarker for detection, prognosis and } \\
\text { prediction for recurrence and response to taxane } \\
\text { chemotherapy. }\end{array}$ & {$[119,120]$} \\
\hline HMMR-AS1 & ENSG00000251018 & $\mathrm{NAT}(\mathrm{nc} \mid \mathrm{pc})$ & HMMR & Upregulation/Oncogenic & Involved in cell proliferation and invasion. & $\begin{array}{l}\text { Positive correlation with HMMR, BRCA1, BRCA2 } \\
\text { (oncogenic), biomarker and potential target in } \\
\text { basal-like breast cancer. }\end{array}$ & [121] \\
\hline
\end{tabular}


Table 1. Cont.

\begin{tabular}{|c|c|c|c|c|c|c|c|}
\hline $\begin{array}{l}\text { IncRNA in } \\
\text { Breast Cancer }\end{array}$ & Access Number & Type & pcGene & $\begin{array}{l}\text { Alteration/Role in } \\
\text { Breast Cancer }\end{array}$ & Mechanism of Action & Therapeutic Utility & Ref. \\
\hline HOTAIR & ENSG00000228630 & $\begin{array}{c}\text { NAT } \\
\text { (nc| pc)/lincRNA } \\
\text { (multiple transcripts) }\end{array}$ & HOXC11 & Upregulation/Oncogenic & $\begin{array}{l}\text { Guides epigenetic mechanisms to silence tumor suppressor genes } \\
\text { through interaction with PRC2 and LSD1, involved in protein } \\
\text { degradation by interaction with E3-ubiquitin ligases, tumor } \\
\text { invasion, apoptosis and EMT. }\end{array}$ & $\begin{array}{l}\text { Over-expressed in cancer, biomarker and potential } \\
\text { therapeutic target. }\end{array}$ & $\begin{array}{l}{[86,89,122-} \\
127]\end{array}$ \\
\hline HOTAIRM1 & ENSG00000233429 & $\begin{array}{c}\text { NAT } \\
\text { (ncl pc)/bidirectional } \\
\text { IncRNA (multiple } \\
\text { transcripts) }\end{array}$ & $\begin{array}{l}\text { HOXA1, } \\
\text { HOXA2 }\end{array}$ & Upregulation/Oncogenic & $\begin{array}{l}\text { Modulates gene expression in HoxA gene cluster by interacting } \\
\text { with PRC1 and PRC } 2 \text { complexes. High positive correlation with } \\
\text { HOXA1 expression. }\end{array}$ & Increased in basal-like subtype breast cancer. & {$[128,129]$} \\
\hline HOXA-AS2 & ENSG00000253552 & NAT (nclpc) & $\begin{array}{l}\text { HOXA3, } \\
\text { HOXA4 }\end{array}$ & Upregulation/Oncogenic & $\begin{array}{l}\text { Acts as an endogenous sponge of miR-520c-3p and indirectly } \\
\text { controls the expression of miR520c-3p target genes (TGFBR2 and } \\
R E L A) \text {. }\end{array}$ & & [130] \\
\hline HOXA11-AS & ENSG00000240990 & $\mathrm{NAT}(\mathrm{nc} \mid \mathrm{pc})$ & HOXA11 & Upregulation/Oncogenic & $\begin{array}{l}\text { Promotes cell proliferation, invasion and metastasis by } \\
\text { regulating EMT. }\end{array}$ & $\begin{array}{l}\text { Biomarker for metastasis and prognosis in breast } \\
\text { cancer. Blocked relation between HOXA11-AS and } \\
\text { EMT may have therapeutic utility. }\end{array}$ & [131] \\
\hline Lnc-ITGB1-6:7 & $\begin{array}{l}\text { Lnc-ITGB1-6 } \\
\text { (LNCipedia) }\end{array}$ & lincRNA & & Upregulation/Oncogenic & $\begin{array}{l}\text { Promotes cell proliferation, invasion and metastasis by } \\
\text { regulating EMT. High linc-ITGB1 expression is associated with } \\
\text { poor prognosis. }\end{array}$ & Biomarker in prognosis of breast cancer. & {$[132,133]$} \\
\hline Linc-RoR & ENSG00000258609 & lincRNA & & Upregulation/Oncogenic & $\begin{array}{l}\text { Induces EMT. Contributes to tumor growth, invasion, metastasis } \\
\text { and drug resistance through endogenous competition with } \\
\text { various } \operatorname{miR}(145,205,133,34) \text { and inhibition of } p 53 \text { expression. }\end{array}$ & $\begin{array}{l}\text { Upregulation is a marker in multi-drug resistance, } \\
\text { chemotherapy tolerance. Potential therapeutic target } \\
\text { for aggressive and metastatic breast cancer. }\end{array}$ & {$[91,134]$} \\
\hline LINC00472 & ENSG00000233237 & lincRNA & & $\begin{array}{l}\text { Downregulation/Tumor } \\
\text { suppressor }\end{array}$ & $\begin{array}{l}\text { Associated with tumor grade, estrogen receptor status and } \\
\text { molecular subtype in breast cancer. Repressed by methylation of } \\
\text { its promoter. }\end{array}$ & Potential prognosis and predictive biomarker. & {$[135,136]$} \\
\hline LSINCT5 & ENSG00000281560 & lincRNA & & Upregulation/Oncogenic & Promotes cell proliferation. & & [137] \\
\hline MALAT1 & ENSG00000251562 & NAT (nclnc) & & Upregulation/Oncogenic & $\begin{array}{l}\text { Plays a critical role in pre-mRNA alternative splicing. Regulates } \\
\text { EMT gene expression. }\end{array}$ & $\begin{array}{l}\text { Knockdown reduces cell growth, invasion, migration } \\
\text { and differentiation into cystic tumors. Potential } \\
\text { prognosis marker in ER- and prediction marker for } \\
\text { endocrine treatment sensitivity in ER+. }\end{array}$ & [138-141] \\
\hline MEG3 & ENSG00000214548 & NAT (nclnc) & & $\begin{array}{l}\text { Downregulation/Tumor } \\
\text { suppressor }\end{array}$ & $\begin{array}{l}\text { Represses MDM2, leading to p } 53 \text { accumulation. Silences genomic } \\
\text { loci of TGFF-associated genes by interaction with PRC2. } \\
\text { Represses AKT signaling pathway. Inhibits EMT by sponging } \\
\text { miR-421. }\end{array}$ & $\begin{array}{l}\text { Expression promotes apoptosis, inhibits proliferation } \\
\text { and angiogenesis. }\end{array}$ & $\begin{array}{c}{[87,88,142,} \\
143]\end{array}$ \\
\hline $\begin{array}{l}\text { MIR31HG } \\
\text { (LOC554202) }\end{array}$ & ENSG00000171889 & $\begin{array}{l}\text { Sense-overlapping } \\
\text { IncRNA }\end{array}$ & & $\begin{array}{l}\text { Downregulation/Tumor } \\
\text { suppressor }\end{array}$ & $\begin{array}{l}\text { Host gene of miR-31. Silenced in TNBC by promoter } \\
\text { hypermethylation. Inhibits invasion-metastasis cascade by } \\
\text { targeting pro-metastasis genes (i.e., RhoA and WAVE3). }\end{array}$ & & [144-146] \\
\hline NEAT1 & ENSG00000245532 & lincRNA & & Upregulation/Oncogenic & $\begin{array}{l}\text { Modulates miRNA biogenesis by organizing key components of } \\
\text { paraspeckles and regulates transcription through protein } \\
\text { sequestration into paraspeckles. Promotes proliferation and EMT. } \\
\text { In ER+, NEAT1 is indispensable for interaction between FOXN3 } \\
\text { and SINA3 complex. Regulates EZH2 through miR-101. }\end{array}$ & $\begin{array}{l}\text { Overexpression of miR-548ar-3p downregulates } \\
\text { NEAT1 and results in inhibition of cell growth. }\end{array}$ & [147-152] \\
\hline PANDAR & ENSG00000281450 & lincRNA & & Upregulation/Oncogenic & $\begin{array}{l}\text { Represses } 116^{\mathrm{INK} 4 \mathrm{~A}} \text { expression through modulating the } \\
\text { recruitment of Bmi1 to the p16 } 16^{\mathrm{INK} 4 \mathrm{~A}} \text { promoter. Removes cycle } \\
\text { arrest possibility during } \mathrm{G} / \mathrm{S} \text { transition. }\end{array}$ & Potential therapeutic target. & [85] \\
\hline
\end{tabular}


Table 1. Cont.

\begin{tabular}{|c|c|c|c|c|c|c|c|}
\hline $\begin{array}{l}\text { IncRNA in } \\
\text { Breast Cancer }\end{array}$ & Access Number & Type & pcGene & $\begin{array}{l}\text { Alteration/Role in } \\
\text { Breast Cancer }\end{array}$ & Mechanism of Action & Therapeutic Utility & Ref. \\
\hline PTPRG-AS1 & ENSG00000241472 & $\mathrm{NAT}(\mathrm{nc} \mid \mathrm{pc})$ & $\begin{array}{l}\text { PTPRG, } \\
\text { C3ORF14 }\end{array}$ & Upregulation/Oncogenic & & $\begin{array}{l}\text { Differentially expressed between } \mathrm{ER}+\text { and } \\
\mathrm{ER}-\text { subtypes. }\end{array}$ & {$[153,154]$} \\
\hline PVT1 & ENSG00000249859 & NAT $(n c \mid p c)$ & TMEM75 & Upregulation/Oncogenic & $\begin{array}{l}\text { Co-operation between c-Myc and PVT1. Enhances c-Myc stability } \\
\text { through inhibiting its phosphorylation. }\end{array}$ & $\begin{array}{l}\text { Due to synergy between c-Myc and PVT1, silencing } \\
\text { PVT1 expression decreases cell proliferation and } \\
\text { increases apoptosis. Potential therapeutic target. }\end{array}$ & [155-158] \\
\hline SNHG17 & ENSG00000196756 & lincRNA & & & & $\begin{array}{l}\text { Differentially expressed between ER+ and ER- } \\
\text { subtypes. Low expression associated with overall } \\
\text { survival. Expression correlates with tumor grade. }\end{array}$ & [154] \\
\hline SOX2-OT & ENSG00000242808 & $\begin{array}{c}\text { NAT }(\mathrm{nc} \mid \mathrm{pc}) \\
\text { sense-overlapping } \\
\text { lncRNA, lincRNA }\end{array}$ & DNAJC19 & Upregulation/Oncogenic & $\begin{array}{l}\text { Through positive effect on SOX2 expression, SOX2OT plays a key } \\
\text { role in pluripotency and tumorigenesis. }\end{array}$ & Potential prognosis marker and therapeutic target. & {$[159,160]$} \\
\hline SPRY4-IT1 & ENSG00000281881 & $\begin{array}{l}\text { Sense-intronic } \\
\text { lncRNA }\end{array}$ & & Upregulation/Oncogenic & $\begin{array}{l}\text { Upregulates ZNF703 involved in the activation of the mTor } \\
\text { signaling pathway. Promotes cell proliferation and } \\
\text { inhibits apoptosis. }\end{array}$ & $\begin{array}{l}\text { SPRY4-IT1 positively correlates with tumor size and } \\
\text { pathological stage. Prognostic marker and potential } \\
\text { therapeutic target. }\end{array}$ & {$[161,162]$} \\
\hline $\begin{array}{c}\text { TERRA } \\
\text { (Telomeric } \\
\text { repeat-containing } \\
\text { RNA) } \\
\end{array}$ & & $\operatorname{lncRNA}$ & & Misregulation & $\begin{array}{l}\text { Transcribed from telomeric C-rich strand. Interacts with TRF1 } \\
\text { and TRF2 to facilitate heterochromatin formation. Provides RNA } \\
\text { template to aid telomerase function. }\end{array}$ & $\begin{array}{l}\text { Potential therapeutic target to impair } \\
\text { telomerase activity. }\end{array}$ & {$[163-166]$} \\
\hline TP73-AS1 & ENSG00000227372 & NAT $(n c \mid p c)$ & TP73 & Upregulation/Oncogenic & $\begin{array}{l}\text { TP73-AS1 / miR-200a/ZEB1 forms a regulating loop. TP73-AS1 } \\
\text { competes with ZEB1 for binding to miR-200a. ZEB1 binds to } \\
\text { TP73-AS1 promoter and activates its expression. Upregulation of } \\
\text { TP73-AS1/ZEB1 promotes cell invasion and migration. }\end{array}$ & Potential therapeutic target. & {$[94,167]$} \\
\hline treRNA & ENSG00000231265 & lincRNA & & Upregulation/Oncogenic & $\begin{array}{l}\text { Regulates translation through interaction with ribonucleoprotein } \\
\text { complex, which will bind to the translation initiation factor } \\
\text { (EIF4G1). Overexpressed in lymph-node metastasis. Promotes } \\
\text { tumor invasion and metastasis. Regulates expression of } \\
\text { metastasis promoting-gene Snail. Suppresses epithelial markers } \\
\text { and translation of E-cadherin mRNA. }\end{array}$ & & [168] \\
\hline UCA1 & ENSG00000214049 & lincRNA & & Upregulation/Oncogenic & $\begin{array}{l}\text { Enhances chemotherapy resistance (tamoxifen) through mTor } \\
\text { pathway inhibition and miR-18a downregulation. Promotes EMT } \\
\text { through activating Wnt/ } \beta \text {-catenin signaling. UCA1/hnRNP1 } \\
\text { suppresses p27 protein level by competition. Downregulates } \\
\text { tumor suppressor miR-143. }\end{array}$ & $\begin{array}{l}\text { Potential urine biomarker. Knockdown reduces } \\
\text { chemoresistance, cell migration and tumor size. }\end{array}$ & [169-173] \\
\hline ZFAS1 & ENSG00000177410 & $\operatorname{NAT}(n c \mid p c)$ & ZNFX1 & $\begin{array}{l}\text { Downregulation in } \\
\text { breast } \\
\text { cancer/Upregulated in } \\
\text { other cancers }\end{array}$ & $\begin{array}{l}\text { Associated with ribosomes in breast cancer. Role in development } \\
\text { and cell differentiation in mammary gland. }\end{array}$ & Potential biomarker. & [174-178] \\
\hline
\end{tabular}

Abbreviations: nc: non-coding; pc: protein coding; lncRNA: long intergenic non-coding RNA; TNBC: triple negative breast cancer; NAT: natural antisense transcript; EMT: epithelial to mesenchymal transition; ER+ and ER-: estrogen receptor positive and negative breast cancers; G1/S transition: The transition between the two first phases of the cell cycle; ANRASSF1: RASSF1 antisense RNA 1; RASSF1: Ras association domain family member 1; PRC: olycomb repressive complex; ANRIL: antisense non-coding RNA in the INK4 locus; CDKN2A: cyclin dependent kinase inhibitor 2A; CDKN2B: cyclin dependent kinase inhibitor 2B; CBX7: chromobox 7; 
SUZ12: SUZ12 polycomb repressive complex 2 subunit; INK: cyclin dependent kinase inhibitor; LSAMP: limbic system-associated membrane protein; BCAR4: breast cancer anti-estrogen resistance 4; SNIP: SRC kinase signaling inhibitor 1; PNUTS: protein phosphatase 1 regulatory subunit; SMO: smoothened, frizzled class receptor; BCYRN1: brain cytoplasmic RNA 1; CCAT2: colon cancer associated transcript 2; TGFbeta: transforming growth factor beta 1; Wnt: wingless-type MMTV integration site family; CRNDE: colorectal neoplasia differentially expressed; DANCR: differentiation antagonizing non-protein coding RNA; DSCAM-AS1: DSCAM antisense RNA 1; DSCAM: DS cell adhesion molecule; FAM83H-AS1: FAM83H antisense RNA 1; GAS5: growth arrest specific 5; ZBTB37: zinc finger and BTB domain containing 37; GR: glucocorticoïd receptor; H19: H19, imprinted maternally expressed transcript; BIK: BCL2 interacting killer; HIF1A-AS2: HIF1A antisense RNA 2; HIF1A: hypoxia inducible factor 1 alpha subunit; HMMR-AS1: HMMR antisense RNA 1; HMMR: hyaluronan mediated motility receptor; BRCA1: BRCA1, DNA repair associated; BRCA2: BRCA2, DNA repair associated; HOTAIR: HOX transcript antisense RNA; HOXC11: homeobox C11; LSD1: lysine demethylase 1A; HOTAIRM1: HOXA transcript antisense RNA, myeloid-specific 1; HOX: homeobox; HOXA-AS2: HOXA cluster antisense RNA 2; TGFBR2: transforming growth factor beta receptor 2; RELA: RELA proto-oncogene, NF-kB subunit; HOXA11-AS: HOXA11 antisense RNA; LSINCT5: long stress-induced non-coding transcript 5; MALAT1: metastasis associated lung adenocarcinoma transcript 1; MEG3: maternally expressed 3; MDM2: transformed mouse 3T3 cell double minute 2 proto-oncogene; AKT: thymoma viral proto-oncogene serine/threonine kinase 1; RhoA: ras homolog family member A; RhoA: ras homolog family member A; WAVE3: WAS protein family member 3; NEAT1: nuclear paraspeckle assembly transcript 1; FOXN3: forkhead box N3; SINA3: E3 ubiquitin-protein ligase SINAT5-like; PANDAR: promoter of CDKN1A antisense DNA damage activated RNA; Bmi1: BMI1 proto-oncogene, polycomb ring finger; PTPRG-AS1: PTPRG antisense RNA 1; PTPRG: protein tyrosine phosphatase, receptor type G; C3ORF14: chromosome 3 open reading frame 14; PVT1: Pvt1 oncogene; TMEM75: transmembrane protein 75; c-Myc: MYC proto-oncogene, bHLH transcription factor; SNHG17: small nucleolar RNA host gene 17; SOX2-OT: SOX2 overlapping transcript; DNAJC19: DnaJ heat shock protein family (Hsp40) member C19; SOX2: SRY-box 2; SPRY4-IT1: SPRY4 intronic transcript 1; ZNF703: zinc finger protein 703; mTor: mechanistic target of rapamycin kinase; TRF: telomeric repeat binding factor; TP73-AS1: TP73 antisense RNA 1; TP73: tumor protein p73; ZEB1: zinc finger E-box binding homeobox 1; treRNA: translation regulatory long non-coding RNA 1; EIF4G1: eukaryotic translation initiation factor 4 gamma 1; Snail: snail family transcriptional repressor 1; UCA1: urothelial cancer associated 1; ZFAS1: ZNFX1 antisense RNA 1; ZNFX1: zinc finger NFX1-type containing 1. 


\subsection{NATs as Cancer Biomarkers}

Like mRNAs, the expression levels of NATs and lncRNAs are affected under cancerous conditions. Differences in mRNA expression patterns between different subgroups of breast cancer patients have been used to develop genomic tests able to predict patient's prognosis, or to predict treatment response by breast cancers. Among them, we can underline the MammaPrint and PAM50 microarray-based gene signatures, or the Oncotype DX RT-PCR-based assay that can help clinicians make treatment decisions based on the calculation of the recurrence risk, and/or the benefits of chemotherapy in the case of Oncotype DX test [179-181].

Similarly, multiple NATs/lncRNAs display expression levels that are associated with the disease prognosis, the treatment response or the clinical classification of breast cancers (Table 1). Although no clinically validated test has emerged yet, several studies report prognostic ncRNA gene signatures [119,182-185].

\subsection{NATs as Therapeutic Targets}

The understanding of antisense transcription is important for therapies. Indeed, NATs represent a potential highly specific entry point for therapeutic intervention on targeted genes by the use of ASO (antisense oligonucleotides) that are drugs already FDA-approved for several diseases [186].

Functionally characterized NATs can be targeted by ASOs, called in this case antagoNATs, to block the interaction of the sense and antisense transcripts. The hybridization of ASOs with the antisense transcript would lead to its degradation, or to transcriptional de-repression at the chromatin level [187]. The first in vivo demonstration of antagoNAT efficacy was shown by Modarresi et al. [188] and has been validated in other clinical contexts, detailed in the review by MacLeod et al. [187].

\section{Conclusions}

Up to $90 \%$ of the human genome length is transcribed: $\sim 2 \%$ of the genomic DNA is coding for proteins; $\sim 88 \%$ is transcribed but do not encode proteins; and $\sim 10 \%$ is not transcribed. In contrast, $\sim 80 \%$ of the RNA transcripts are coding for proteins and the remaining $20 \%$ do not. These sequences are thus less expressed than the coding ones. They are also less conserved between species than coding genes, but more conserved than the non-coding and the non-transcribed genes. Such transcripts must therefore play a biological role, which has yet to be described.

Among lncRNAs, NATs are coding or non-coding RNA sequences, which are complementary to and overlapping with either protein-coding or non-coding transcripts. Their main biological role is thought to be the regulation of $p c G e n e$ expression through a variety of molecular mechanisms. High-throughput transcriptomic studies have demonstrated that the expression of NATs and lncRNAs is modified under cancerous conditions, making them good cancer biomarkers. Finally, non-coding/pcGene transcript pairs are interesting, especially for specific target-gene treatments using ASO.

Acknowledgments: This work was supported by the French Community of Belgium, Belgian Funds for Scientific Research (F.R.S.-FNRS), the F.R.S.-FNRS-Televie, CHU Liege (F.I.R.S) and the Region Wallonne (XSPRELTRIN).

Author Contributions: Guillaume Latgé and Claire Josse compiled the current literature and wrote the first draft of the article. Christophe Poulet contributed to scientific and language editing. Vincent Bours, Claire Josse and Guy Jerusalem supervised the project. All authors provided critical feedback and helped shape the manuscript writing.

Conflicts of Interest: The authors declare no conflict of interest.

\begin{tabular}{ll}
\multicolumn{2}{l}{ Abbreviations } \\
NAT & Natural antisense transcripts \\
nc & Non-coding \\
pc & Protein-coding \\
ds & Double-stranded
\end{tabular}




$\begin{array}{ll}\text { pcGene } & \text { Protein-coding gene } \\ \text { lncRNA } & \text { Long non-coding RNA } \\ \text { lincRNA } & \text { Long intergenic non-coding RNA } \\ \text { ncRNA } & \text { Non-coding RNA } \\ \text { mRNA } & \text { Messenger RNA } \\ \text { RNA Pol II } & \text { RNA polymerase II } \\ \text { PRC } & \text { Polycomb Repressive Complex } \\ \text { ASO } & \text { Antisense oligonucleotide }\end{array}$

\section{References}

1. Carninci, P.; Kasukawa, T.; Katayama, S.; Gough, J.; Frith, M.C.; Maeda, N.; Oyama, R.; Ravasi, T.; Lenhard, B.; Wells, C.; et al. The transcriptional landscape of the mammalian genome. Science 2005, 309, 1559-1563. [CrossRef] [PubMed]

2. Katayama, S.; Tomaru, Y.; Kasukawa, T.; Waki, K.; Nakanishi, M.; Nakamura, M.; Nishida, H.; Yap, C.C.; Suzuki, M.; Kawai, J.; et al. Antisense transcription in the mammalian transcriptome. Science 2005, 309, 1564-1566. [CrossRef] [PubMed]

3. Djebali, S.; Davis, C.A.; Merkel, A.; Dobin, A.; Lassmann, T.; Mortazavi, A.; Tanzer, A.; Lagarde, J.; Lin, W.; Schlesinger, F.; et al. Landscape of transcription in human cells. Nature 2012, 489, 101-108. [CrossRef] [PubMed]

4. ENCODE Project Consortium; Birney, E.; Stamatoyannopoulos, J.A.; Dutta, A.; Gingeras, T.R.; Margulies, E.H.; Weng, Z.; Snyder, M.; Dermitzakis, E.T.; Thurman, R.E.; et al. Identification and analysis of functional elements in 1\% of the human genome by the ENCODE pilot project. Nature 2007, 447, 799-816. [CrossRef] [PubMed]

5. Nishizawa, M.; Ikeya, Y.; Okumura, T.; Kimura, T. Post-transcriptional inducible gene regulation by natural antisense RNA. Front. Biosci. 2015, 20,1-36. [CrossRef]

6. Kapranov, P.; Cheng, J.; Dike, S.; Nix, D.A.; Duttagupta, R.; Willingham, A.T.; Stadler, P.F.; Hertel, J.; Hackermüller, J.; Hofacker, I.L.; et al. RNA maps reveal new RNA classes and a possible function for pervasive transcription. Science 2007, 316, 1484-1488. [CrossRef] [PubMed]

7. Taft, R.J.; Pang, K.C.; Mercer, T.R.; Dinger, M.; Mattick, J.S. Non-coding RNAs: Regulators of disease. J. Pathol. 2010, 220, 126-139. [CrossRef] [PubMed]

8. Palazzo, A.F.; Lee, E.S. Non-coding RNA: What is functional and what is junk? Front. Genet. $2015,6,2$. [CrossRef] [PubMed]

9. Mattick, J.S.; Makunin, I.V. Non-coding RNA. Hum. Mol. Genet. 2006, 15, R17-R29. [CrossRef] [PubMed]

10. Mortazavi, A.; Williams, B.A.; McCue, K.; Schaeffer, L.; Wold, B. Mapping and quantifying mammalian transcriptomes by RNA-Seq. Nat. Methods 2008, 5, 621-628. [CrossRef] [PubMed]

11. Kellis, M.; Wold, B.; Snyder, M.P.; Bernstein, B.E.; Kundaje, A.; Marinov, G.K.; Ward, L.D.; Birney, E.; Crawford, G.E.; Dekker, J.; et al. Defining functional DNA elements in the human genome. Proc. Natl. Acad. Sci. USA 2014, 111, 6131-6138. [CrossRef] [PubMed]

12. Frankish, A.; Uszczynska, B.; Ritchie, G.R.S.; Gonzalez, J.M.; Pervouchine, D.; Petryszak, R.; Mudge, J.M.; Fonseca, N.; Brazma, A.; Guigo, R.; et al. Comparison of GENCODE and RefSeq gene annotation and the impact of reference geneset on variant effect prediction. BMC Genom. 2015, 16 (Suppl. 8), S2. [CrossRef] [PubMed]

13. Jalali, S.; Gandhi, S.; Scaria, V. Navigating the dynamic landscape of long noncoding RNA and protein-coding gene annotations in GENCODE. Hum. Genom. 2016, 10, 35. [CrossRef] [PubMed]

14. Zhao, Y.; Li, H.; Fang, S.; Kang, Y.; Wu, W.; Hao, Y.; Li, Z.; Bu, D.; Sun, N.; Zhang, M.Q.; et al. NONCODE 2016: An informative and valuable data source of long non-coding RNAs. Nucleic Acids Res. 2016, 44, D203-D208. [CrossRef] [PubMed]

15. The RNAcentral Consortium. RNAcentral: A comprehensive database of non-coding RNA sequences. Nucleic Acids Res. 2017, 45, D128-D134. [CrossRef]

16. Volders, P.-J.; Helsens, K.; Wang, X.; Menten, B.; Martens, L.; Gevaert, K.; Vandesompele, J.; Mestdagh, P. LNCipedia: A database for annotated human lncRNA transcript sequences and structures. Nucleic Acids Res. 2013, 41, D246-D251. [CrossRef] [PubMed] 
17. Wilusz, J.E.; Sunwoo, H.; Spector, D.L. Long noncoding RNAs: Functional surprises from the RNA world. Genes Dev. 2009, 23, 1494-1504. [CrossRef] [PubMed]

18. Derrien, T.; Johnson, R.; Bussotti, G.; Tanzer, A.; Djebali, S.; Tilgner, H.; Guernec, G.; Martin, D.; Merkel, A.; Knowles, D.G.; et al. The GENCODE v7 catalog of human long noncoding RNAs: Analysis of their gene structure, evolution, and expression. Genome Res. 2012, 22, 1775-1789. [CrossRef] [PubMed]

19. Ma, L.; Bajic, V.B.; Zhang, Z. On the classification of long non-coding RNAs. RNA Biol. 2013, 10, 925-933. [CrossRef] [PubMed]

20. Nakaya, H.I.; Amaral, P.P.; Louro, R.; Lopes, A.; Fachel, A.A.; Moreira, Y.B.; El-Jundi, T.A.; da Silva, A.M.; Reis, E.M.; Verjovski-Almeida, S. Genome mapping and expression analyses of human intronic noncoding RNAs reveal tissue-specific patterns and enrichment in genes related to regulation of transcription. Genome Biol. 2007, 8, R43. [CrossRef] [PubMed]

21. St Laurent, G.; Savva, Y.A.; Kapranov, P. Dark matter RNA: An intelligent scaffold for the dynamic regulation of the nuclear information landscape. Front. Genet. 2012, 3, 57. [CrossRef] [PubMed]

22. Gardner, E.J.; Nizami, Z.F.; Talbot, C.C., Jr.; Gall, J.G. Stable intronic sequence RNA (sisRNA), a new class of noncoding RNA from the oocyte nucleus of Xenopus tropicalis. Genes Dev. 2012, 26, 2550-2559. [CrossRef] [PubMed]

23. Guttman, M.; Amit, I.; Garber, M.; French, C.; Lin, M.F.; Feldser, D.; Huarte, M.; Zuk, O.; Carey, B.W.; Cassady, J.P.; et al. Chromatin signature reveals over a thousand highly conserved large non-coding RNAs in mammals. Nature 2009, 458, 223-237. [CrossRef] [PubMed]

24. Ponting, C.P.; Oliver, P.L.; Reik, W. Evolution and functions of long noncoding RNAs. Cell 2009, 136, 629-641. [CrossRef] [PubMed]

25. Amaral, P.P.; Clark, M.B.; Gascoigne, D.K.; Dinger, M.E.; Mattick, J.S. lncRNAdb: A reference database for long noncoding RNAs. Nucleic Acids Res. 2011, 39, D146-D151. [CrossRef] [PubMed]

26. St Laurent, G.; Shtokalo, D.; Dong, B.; Tackett, M.R.; Fan, X.; Lazorthes, S.; Nicolas, E.; Sang, N.; Triche, T.J.; McCaffrey, T.A.; et al. VlincRNAs controlled by retroviral elements are a hallmark of pluripotency and cancer. Genome Biol. 2013, 14, R73. [CrossRef] [PubMed]

27. Dinger, M.E.; Pang, K.C.; Mercer, T.R.; Mattick, J.S. Differentiating protein-coding and noncoding RNA: Challenges and ambiguities. PLoS Comput. Biol. 2008, 4, e1000176. [CrossRef] [PubMed]

28. Chen, L.-L.; Carmichael, G.G. Long noncoding RNAs in mammalian cells: What, where, and why? Wiley Interdiscip. Rev. RNA 2010, 1, 2-21. [CrossRef] [PubMed]

29. Yoon, J.-H.; Abdelmohsen, K.; Gorospe, M. Posttranscriptional gene regulation by long noncoding RNA. J. Mol. Biol. 2013, 425, 3723-3730. [CrossRef] [PubMed]

30. Vance, K.W.; Ponting, C.P. Transcriptional regulatory functions of nuclear long noncoding RNAs. Trends tGenet. 2014, 30, 348-355. [CrossRef] [PubMed]

31. Dinger, M.E.; Amaral, P.P.; Mercer, T.R.; Pang, K.C.; Bruce, S.J.; Gardiner, B.B.; Askarian-Amiri, M.E.; Ru, K.; Soldà, G.; Simons, C.; et al. Long noncoding RNAs in mouse embryonic stem cell pluripotency and differentiation. Genome Res. 2008, 18, 1433-1445. [CrossRef] [PubMed]

32. Maenner, S.; Müller, M.; Becker, P.B. Roles of long, non-coding RNA in chromosome-wide transcription regulation: Lessons from two dosage compensation systems. Biochimie 2012, 94, 1490-1498. [CrossRef] [PubMed]

33. Kitagawa, M.; Kitagawa, K.; Kotake, Y.; Niida, H.; Ohhata, T. Cell cycle regulation by long non-coding RNAs. Cell. Mol. Life Sci. 2013, 70, 4785-4794. [CrossRef] [PubMed]

34. Grammatikakis, I.; Panda, A.C.; Abdelmohsen, K.; Gorospe, M. Long noncoding RNAs(lncRNAs) and the molecular hallmarks of aging. Aging 2014, 6, 992-1009. [CrossRef] [PubMed]

35. Zhao, Z.; Dammert, M.A.; Hoppe, S.; Bierhoff, H.; Grummt, I. Heat shock represses rRNA synthesis by inactivation of TIF-IA and lncRNA-dependent changes in nucleosome positioning. Nucleic Acids Res. 2016, 44, 8144-8152. [CrossRef] [PubMed]

36. Angrand, P.-O.; Vennin, C.; Le Bourhis, X.; Adriaenssens, E. The role of long non-coding RNAs in genome formatting and expression. Front. Genet. 2015, 6, 165. [CrossRef] [PubMed]

37. Mercer, T.R.; Dinger, M.E.; Mattick, J.S. Long non-coding RNAs: Insights into functions. Nat. Rev. Genet. 2009, 10, 155-159. [CrossRef] [PubMed] 
38. Tsuiji, H.; Yoshimoto, R.; Hasegawa, Y.; Furuno, M.; Yoshida, M.; Nakagawa, S. Competition between a noncoding exon and introns: Gomafu contains tandem UACUAAC repeats and associates with splicing factor-1. Genes Cells 2011, 16, 479-490. [CrossRef] [PubMed]

39. Balbin, O.A.; Malik, R.; Dhanasekaran, S.M.; Prensner, J.R.; Cao, X.; Wu, Y.-M.; Robinson, D.; Wang, R.; Chen, G.; Beer, D.G.; et al. The landscape of antisense gene expression in human cancers. Genome Res. 2015, 25, 1068-1079. [CrossRef] [PubMed]

40. Li, J.-T.; Zhang, Y.; Kong, L.; Liu, Q.-R.; Wei, L. Trans-natural antisense transcripts including noncoding RNAs in 10 species: Implications for expression regulation. Nucleic Acids Res. 2008, 36, 4833-4844. [CrossRef] [PubMed]

41. Vanhée-Brossollet, C.; Vaquero, C. Do natural antisense transcripts make sense in eukaryotes? Gene 1998, 211, 1-9. [CrossRef]

42. Seila, A.C.; Calabrese, J.M.; Levine, S.S.; Yeo, G.W.; Rahl, P.B.; Flynn, R.A.; Young, R.A.; Sharp, P.A. Divergent transcription from active promoters. Science 2008, 322, 1849-1851. [CrossRef] [PubMed]

43. Lin, S.; Zhang, L.; Luo, W.; Zhang, X. Characteristics of antisense transcript promoters and the regulation of their activity. Int. J. Mol. Sci. 2016, 17, 9. [CrossRef] [PubMed]

44. Patton, J.; Block, S.; Coombs, C.; Martin, M.E. Identification of functional elements in the murine Gabp alpha / ATP synthase coupling factor 6 bi-directional promoter. Gene 2006, 369, 35-44. [CrossRef] [PubMed]

45. Schuettengruber, B.; Doetzlhofer, A.; Kroboth, K.; Wintersberger, E.; Seiser, C. Alternate activation of two divergently transcribed mouse genes from a bidirectional promoter is linked to changes in histone modification. J. Biol. Chem. 2003, 278, 1784-1793. [CrossRef] [PubMed]

46. Grinchuk, O.V.; Motakis, E.; Yenamandra, S.P.; Ow, G.S.; Jenjaroenpun, P.; Tang, Z.; Yarmishyn, A.A.; Ivshina, A.V.; Kuznetsov, V.A. Sense-antisense gene-pairs in breast cancer and associated pathological pathways. Oncotarget 2015, 6, 42197-42221. [CrossRef] [PubMed]

47. Whitehouse, I.; Rando, O.J.; Delrow, J.; Tsukiyama, T. Chromatin remodelling at promoters suppresses antisense transcription. Nature 2007, 450, 1031-1035. [CrossRef] [PubMed]

48. Kim, T.; Xu, Z.; Clauder-Münster, S.; Steinmetz, L.M.; Buratowski, S. Set3 HDAC mediates effects of overlapping noncoding transcription on gene induction kinetics. Cell 2012, 150, 1158-1169. [CrossRef] [PubMed]

49. Giannakakis, A.; Zhang, J.; Jenjaroenpun, P.; Nama, S.; Zainolabidin, N.; Aau, M.Y.; Yarmishyn, A.A.; Vaz, C.; Ivshina, A.V.; Grinchuk, O.V.; et al. Contrasting expression patterns of coding and noncoding parts of the human genome upon oxidative stress. Sci. Rep. 2015, 5, 9737. [CrossRef] [PubMed]

50. Wenric, S.; ElGuendi, S.; Caberg, J.-H.; Bezzaou, W.; Fasquelle, C.; Charloteaux, B.; Karim, L.; Hennuy, B.; Frères, P.; Collignon, J.; et al. Transcriptome-wide analysis of natural antisense transcripts shows their potential role in breast cancer. Sci. Rep. 2017, 7, 17452. [CrossRef] [PubMed]

51. Pelechano, V.; Steinmetz, L.M. Gene regulation by antisense transcription. Nat. Rev. Genet. 2013, 14, 880-893. [CrossRef] [PubMed]

52. Rosikiewicz, W.; Makałowska, I. Biological functions of natural antisense transcripts. Acta Biochim. Pol. 2016, 63, 665-673. [CrossRef] [PubMed]

53. Makalowska, I.; Lin, C.-F.; Makalowski, W. Overlapping genes in vertebrate genomes. Comput. Biol. Chem. 2005, 29, 1-12. [CrossRef] [PubMed]

54. Shearwin, K.E.; Callen, B.P.; Egan, J.B. Transcriptional interference-a crash course. Trends Genet. 2005, 21, 339-345. [CrossRef] [PubMed]

55. Stojic, L.; Niemczyk, M.; Orjalo, A.; Ito, Y.; Ruijter, A.E.M.; Uribe-Lewis, S.; Joseph, N.; Weston, S.; Menon, S.; Odom, D.T.; et al. Transcriptional silencing of long noncoding RNA GNG12-AS1 uncouples its transcriptional and product-related functions. Nat. Commun. 2016, 7, 10406. [CrossRef] [PubMed]

56. Oeder, S.; Mages, J.; Flicek, P.; Lang, R. Uncovering information on expression of natural antisense transcripts in Affymetrix MOE430 datasets. BMC Genom. 2007, 8, 200. [CrossRef] [PubMed]

57. Grigoriadis, A.; Oliver, G.R.; Tanney, A.; Kendrick, H.; Smalley, M.J.; Jat, P.; Neville, A.M. Identification of differentially expressed sense and antisense transcript pairs in breast epithelial tissues. BMC Genom. 2009, 10, 324. [CrossRef] [PubMed]

58. Conley, A.B.; Jordan, I.K. Epigenetic regulation of human cis-natural antisense transcripts. Nucleic Acids Res. 2012, 40, 1438-1445. [CrossRef] [PubMed] 
59. Ling, M.H.T.; Ban, Y.; Wen, H.; Wang, S.M.; Ge, S.X. Conserved expression of natural antisense transcripts in mammals. BMC Genom. 2013, 14, 243. [CrossRef] [PubMed]

60. Zhao, Y.; Sun, H.; Wang, H. Long noncoding RNAs in DNA methylation: New players stepping into the old game. Cell Biosci. 2016, 6, 45. [CrossRef] [PubMed]

61. Khorkova, O.; Myers, A.J.; Hsiao, J.; Wahlestedt, C. Natural antisense transcripts. Hum. Mol. Genet. 2014, 23, R54-R63. [CrossRef] [PubMed]

62. Davidovich, C.; Cech, T.R. The recruitment of chromatin modifiers by long noncoding RNAs: Lessons from PRC2. RNA 2015, 21, 2007-2022. [CrossRef] [PubMed]

63. Meseure, D.D.; Vacher, S.; Alsibai, K.D.; Nicolas, A.; Chemlali, W.; Caly, M.; Lidereau, R.; Pasmant, E.; Callens, C.; Bieche, I. Expression of ANRIL-Polycomb Complexes-CDKN2A/B/ARF Genes in Breast Tumors: Identification of a Two-Gene (EZH2/CBX7) Signature with Independent Prognostic Value. Mol. Cancer Res. 2016, 14, 623-633. [CrossRef] [PubMed]

64. Kotake, Y.; Nakagawa, T.; Kitagawa, K.; Suzuki, S.; Liu, N.; Kitagawa, M.; Xiong, Y. Long non-coding RNA ANRIL is required for the PRC2 recruitment to and silencing of p15(INK4B) tumor suppressor gene. Oncogene 2011, 30, 1956-1962. [CrossRef] [PubMed]

65. Aguilo, F.; Zhou, M.-M.; Walsh, M.J. Long noncoding RNA, polycomb, and the ghosts haunting INK4b-ARF-INK4a expression. Cancer Res. 2011, 71, 5365-5369. [CrossRef] [PubMed]

66. Congrains, A.; Kamide, K.; Ohishi, M.; Rakugi, H. ANRIL: Molecular mechanisms and implications in human health. Int. J. Mol. Sci. 2013, 14, 1278-1292. [CrossRef] [PubMed]

67. Deng, Q.; Sun, H.; He, B.; Pan, Y.; Gao, T.; Chen, J.; Ying, H.; Liu, X.; Wang, F.; Xu, Y.; et al. Prognostic value of long non-coding RNA HOTAIR in various cancers. PLoS ONE 2014, 9, e110059. [CrossRef] [PubMed]

68. Bhan, A.; Mandal, S.S. LncRNA HOTAIR: A master regulator of chromatin dynamics and cancer. Biochim. Biophys. Acta 2015, 1856, 151-164. [CrossRef] [PubMed]

69. Rinn, J.L.; Kertesz, M.; Wang, J.K.; Squazzo, S.L.; Xu, X.; Brugmann, S.A.; Goodnough, L.H.; Helms, J.A.; Farnham, P.J.; Segal, E.; et al. Functional demarcation of active and silent chromatin domains in human HOX loci by noncoding RNAs. Cell 2007, 129, 1311-1323. [CrossRef] [PubMed]

70. Sun, J.; Wang, X.; Fu, C.; Wang, X.; Zou, J.; Hua, H.; Bi, Z. Long noncoding RNA FGFR3-AS1 promotes osteosarcoma growth through regulating its natural antisense transcript FGFR3. Mol. Biol. Rep. 2016, 43, 427-436. [CrossRef] [PubMed]

71. Zong, X.; Nakagawa, S.; Freier, S.M.; Fei, J.; Ha, T.; Prasanth, S.G.; Prasanth, K.V. Natural antisense RNA promotes $3^{\prime}$ end processing and maturation of MALAT1 lncRNA. Nucleic Acids Res. 2016, 44, 2898-2908. [CrossRef] [PubMed]

72. Beltran, M.; Puig, I.; Peña, C.; García, J.M.; Alvarez, A.B.; Peña, R.; Bonilla, F.; de Herreros, A.G. A natural antisense transcript regulates Zeb2/Sip1 gene expression during Snail1-induced epithelial-mesenchymal transition. Genes Dev. 2008, 22, 756-769. [CrossRef] [PubMed]

73. Nishikura, K. Functions and regulation of RNA editing by ADAR deaminases. Annu. Rev. Biochem. 2010, 79, 321-349. [CrossRef] [PubMed]

74. Zhang, Z.; Carmichael, G.G. The fate of dsRNA in the nucleus: A p54(nrb)-containing complex mediates the nuclear retention of promiscuously A-to-I edited RNAs. Cell 2001, 106, 465-475. [CrossRef]

75. Levanon, E.Y.; Eisenberg, E.; Yelin, R.; Nemzer, S.; Hallegger, M.; Shemesh, R.; Fligelman, Z.Y.; Shoshan, A.; Pollock, S.R.; Sztybel, D.; et al. Systematic identification of abundant A-to-I editing sites in the human transcriptome. Nat. Biotechnol. 2004, 22, 1001-1005. [CrossRef] [PubMed]

76. Ramaswami, G.; Li, J.B. RADAR: A rigorously annotated database of A-to-I RNA editing. Nucleic Acids Res. 2014, 42, D109-D113. [CrossRef] [PubMed]

77. Neeman, Y.; Dahary, D.; Levanon, E.Y.; Sorek, R.; Eisenberg, E. Is there any sense in antisense editing? Trends Genet. 2005, 21, 544-547. [CrossRef] [PubMed]

78. Salameh, A.; Lee, A.K.; Cardó-Vila, M.; Nunes, D.N.; Efstathiou, E.; Staquicini, F.I.; Dobroff, A.S.; Marchiò, S.; Navone, N.M.; Hosoya, H.; et al. PRUNE2 is a human prostate cancer suppressor regulated by the intronic long noncoding RNA PCA3. Proc. Natl. Acad. Sci. USA 2015, 112, 8403-8408. [CrossRef] [PubMed]

79. Hannon, G.J. RNA interference. Nature 2002, 418, 244-251. [CrossRef] [PubMed]

80. Czech, B.; Hannon, G.J. Small RNA sorting: Matchmaking for Argonautes. Nat. Rev. Genet. 2011, 12, $19-31$. [CrossRef] [PubMed] 
81. Polikepahad, S.; Corry, D.B. Profiling of T helper cell-derived small RNAs reveals unique antisense transcripts and differential association of miRNAs with argonaute proteins 1 and 2. Nucleic Acids Res. 2013, 41, 1164-1177. [CrossRef] [PubMed]

82. Werner, A.; Cockell, S.; Falconer, J.; Carlile, M.; Alnumeir, S.; Robinson, J. Contribution of natural antisense transcription to an endogenous siRNA signature in human cells. BMC Genom. 2014, 15, 19. [CrossRef] [PubMed]

83. Yu, D.; Meng, Y.; Zuo, Z.; Xue, J.; Wang, H. NATpipe: An integrative pipeline for systematical discovery of natural antisense transcripts (NATs) and phase-distributed nat-siRNAs from de novo assembled transcriptomes. Sci. Rep. 2016, 6, 21666. [CrossRef] [PubMed]

84. Beckedorff, F.C.; Ayupe, A.C.; Crocci-Souza, R.; Amaral, M.S.; Nakaya, H.I.; Soltys, D.T.; Menck, C.F.M.; Reis, E.M.; Verjovski-Almeida, S. The intronic long noncoding RNA ANRASSF1 recruits PRC2 to the RASSF1A promoter, reducing the expression of RASSF1A and increasing cell proliferation. PLoS Genet. 2013, 9, e1003705. [CrossRef] [PubMed]

85. Sang, Y.; Tang, J.; Li, S.; Li, L.; Tang, X.; Cheng, C.; Luo, Y.; Qian, X.; Deng, L.-M.; Liu, L.; et al. LncRNA PANDAR regulates the G1/S transition of breast cancer cells by suppressing p16(INK4A) expression. Sci. Rep. 2016, 6, 22366. [CrossRef] [PubMed]

86. Yu, Y.; Lv, F.; Liang, D.; Yang, Q.; Zhang, B.; Lin, H.; Wang, X.; Qian, G.; Xu, J.; You, W. HOTAIR may regulate proliferation, apoptosis, migration and invasion of MCF-7 cells through regulating the P53/Akt/JNK signaling pathway. Biomed. Pharmacother. 2017, 90, 555-561. [CrossRef] [PubMed]

87. Sun, L.; Li, Y.; Yang, B. Downregulated long non-coding RNA MEG3 in breast cancer regulates proliferation, migration and invasion by depending on p53's transcriptional activity. Biochem. Biophys. Res. Commun. 2016, 478, 323-329. [CrossRef] [PubMed]

88. Zhang, C.-Y.; Yu, M.-S.; Li, X.; Zhang, Z.; Han, C.-R.; Yan, B. Overexpression of long non-coding RNA MEG3 suppresses breast cancer cell proliferation, invasion, and angiogenesis through AKT pathway. Tumour. Biol. 2017, 39. [CrossRef] [PubMed]

89. Deng, J.; Yang, M.; Jiang, R.; An, N.; Wang, X.; Liu, B. Long non-coding RNA HOTAIR regulates the proliferation, self-renewal capacity, tumor formation and migration of the cancer stem-like cell (CSC) subpopulation enriched from breast cancer cells. PLoS ONE 2017, 12, e0170860. [CrossRef] [PubMed]

90. Jene-Sanz, A.; Váraljai, R.; Vilkova, A.V.; Khramtsova, G.F.; Khramtsov, A.I.; Olopade, O.I.; Lopez-Bigas, N.; Benevolenskaya, E.V. Expression of polycomb targets predicts breast cancer prognosis. Mol. Cell. Biol. 2013, 33, 3951-3961. [CrossRef] [PubMed]

91. Chen, Y.-M.; Liu, Y.; Wei, H.-Y.; Lv, K.-Z.; Fu, P. Linc-ROR induces epithelial-mesenchymal transition and contributes to drug resistance and invasion of breast cancer cells. Tumour. Biol. 2016, 37, 10861-10870. [CrossRef] [PubMed]

92. Zhou, W.; Ye, X.-L.; Xu, J.; Cao, M.-G.; Fang, Z.-Y.; Li, L.-Y.; Guan, G.-H.; Liu, Q.; Qian, Y.-H.; Xie, D. The lncRNA H19 mediates breast cancer cell plasticity during EMT and MET plasticity by differentially sponging miR-200b/c and let-7b. Sci. Signal. 2017, 10. [CrossRef] [PubMed]

93. Hou, P.; Zhao, Y.; Li, Z.; Yao, R.; Ma, M.; Gao, Y.; Zhao, L.; Zhang, Y.; Huang, B.; Lu, J. LincRNA-ROR induces epithelial-to-mesenchymal transition and contributes to breast cancer tumorigenesis and metastasis. Cell Death Dis. 2014, 5, e1287. [CrossRef] [PubMed]

94. Zou, Q.; Zhou, E.; Xu, F.; Zhang, D.; Yi, W.; Yao, J. A TP73-AS1/miR-200a/ZEB1 regulating loop promotes breast cancer cell invasion and migration. J. Cell. Biochem. 2017. [CrossRef] [PubMed]

95. Chi, Y.; Huang, S.; Yuan, L.; Liu, M.; Huang, N.; Zhou, S.; Zhou, B.; Wu, J. Role of BC040587 as a predictor of poor outcome in breast cancer. Cancer Cell Int. 2014, 14, 123. [CrossRef] [PubMed]

96. Xing, Z.; Lin, C.; Yang, L. Unraveling the therapeutic potential of the LncRNA-dependent noncanonical Hedgehog pathway in cancer. Mol. Cell. Oncol. 2015, 2, e998900. [CrossRef] [PubMed]

97. Xing, Z.; Park, P.K.; Lin, C.; Yang, L. LncRNA BCAR4 wires up signaling transduction in breast cancer. RNA Biol. 2015, 12, 681-689. [CrossRef] [PubMed]

98. Booy, E.P.; McRae, E.K.; Koul, A.; Lin, F.; McKenna, S.A. The long non-coding RNA BC200 (BCYRN1) is critical for cancer cell survival and proliferation. Mol. Cancer 2017, 16, 109. [CrossRef] [PubMed]

99. Redis, R.S.; Sieuwerts, A.M.; Look, M.P.; Tudoran, O.; Ivan, C.; Spizzo, R.; Zhang, X.; de Weerd, V.; Shimizu, M.; Ling, H.; et al. CCAT2, a novel long non-coding RNA in breast cancer: Expression study and clinical correlations. Oncotarget 2013, 4, 1748-1762. [CrossRef] [PubMed] 
100. Deng, X.; Zhao, Y.; Wu, X.; Song, G. Upregulation of CCAT2 promotes cell proliferation by repressing the P15 in breast cancer. Biomed. Pharmacother. 2017, 91, 1160-1166. [CrossRef] [PubMed]

101. Wu, Z.-J.; Li, Y.; Wu, Y.-Z.; Wang, Y.; Nian, W.-Q.; Wang, L.-L.; Li, L.-C.; Luo, H.-L.; Wang, D.-L. Long non-coding RNA CCAT2 promotes the breast cancer growth and metastasis by regulating TGF-beta signaling pathway. Eur. Rev. Med. Pharmacol. Sci. 2017, 21, 706-714. [PubMed]

102. Cai, Y.; He, J.; Zhang, D. Long noncoding RNA CCAT2 promotes breast tumor growth by regulating the Wnt signaling pathway. OncoTargets Ther. 2015, 8, 2657-2664. [CrossRef]

103. Sarrafzadeh, S.; Geranpayeh, L.; Tasharrofi, B.; Soudyab, M.; Nikpayam, E.; Iranpour, M.; Mirfakhraie, R.; Gharesouran, J.; Ghafouri-Fard, S.; Ghafouri-Fard, S. Expression study and clinical correlations of MYC and CCAT2 in breast cancer patients. Iran. Biomed. J. 2017, 21, 303-311. [CrossRef] [PubMed]

104. Huan, J.; Xing, L.; Lin, Q.; Xui, H.; Qin, X. Long noncoding RNA CRNDE activates Wnt/beta-catenin signaling pathway through acting as a molecular sponge of microRNA-136 in human breast cancer. Am. J. Transl. Res. 2017, 9, 1977-1989. [PubMed]

105. Sha, S.; Yuan, D.; Liu, Y.; Han, B.; Zhong, N. Targeting long non-coding RNA DANCR inhibits triple negative breast cancer progression. Biol. Open 2017, 6, 1310-1316. [CrossRef] [PubMed]

106. Miano, V.; Ferrero, G.; Reineri, S.; Caizzi, L.; Annaratone, L.; Ricci, L.; Cutrupi, S.; Castellano, I.; Cordero, F.; de Bortoli, M. Luminal long non-coding RNAs regulated by estrogen receptor alpha in a ligand-independent manner show functional roles in breast cancer. Oncotarget 2015, 7, 3201-3216. [CrossRef] [PubMed]

107. Niknafs, Y.S.; Han, S.; Ma, T.; Speers, C.; Zhang, C.; Wilder-Romans, K.; Iyer, M.K.; Pitchiaya, S.; Malik, R.; Hosono, Y.; et al. The lncRNA landscape of breast cancer reveals a role for DSCAM-AS1 in breast cancer progression. Nat. Commun. 2016, 7, 12791. [CrossRef] [PubMed]

108. Yang, F.; Lv, S.-X.; Lv, L.; Liu, Y.-H.; Dong, S.-Y.; Yao, Z.-H.; Dai, X.-X.; Zhang, X.-H.; Wang, O.-C. Identification of lncRNA FAM83H-AS1 as a novel prognostic marker in luminal subtype breast cancer. OncoTargets Ther. 2016, 9, 7039-7045. [CrossRef] [PubMed]

109. Guo, C.; Song, W.-Q.; Sun, P.; Jin, L.; Dai, H.-Y. LncRNA-GAS5 induces PTEN expression through inhibiting miR-103 in endometrial cancer cells. J. Biomed. Sci. 2015, 22, 100. [CrossRef] [PubMed]

110. Yu, X.; Li, Z. Long non-coding RNA growth arrest-specific transcript 5 in tumor biology. Oncol. Lett. 2015, 10, 1953-1958. [CrossRef] [PubMed]

111. Pickard, M.R.; Williams, G.T. The hormone response element mimic sequence of GAS5 lncRNA is sufficient to induce apoptosis in breast cancer cells. Oncotarget 2016, 7, 10104-10116. [CrossRef] [PubMed]

112. Mourtada-Maarabouni, M.; Pickard, M.R.; Hedge, V.L.; Farzaneh, F.; Williams, G.T. GAS5, a non-protein-coding RNA, controls apoptosis and is downregulated in breast cancer. Oncogene 2009, 28, 195-208. [CrossRef] [PubMed]

113. Li, W.; Zhai, L.; Wang, H.; Liu, C.; Zhang, J.; Chen, W.; Wei, Q. Downregulation of LncRNA GAS5 causes trastuzumab resistance in breast cancer. Oncotarget 2016, 7, 27778-27786. [CrossRef] [PubMed]

114. Han, L.; Ma, P.; Liu, S.-M.; Zhou, X. Circulating long noncoding RNA GAS5 as a potential biomarker in breast cancer for assessing the surgical effects. Tumour. Biol. 2016, 37, 6847-6854. [CrossRef] [PubMed]

115. Li, Z.; Li, Y.; Li, Y.; Ren, K.; Li, X.; Han, X.; Wang, J. Long non-coding RNA H19 promotes the proliferation and invasion of breast cancer through upregulating DNMT1 expression by sponging miR-152. J. Biochem. Mol. Toxicol. 2017, 31. [CrossRef] [PubMed]

116. Si, X.; Zang, R.; Zhang, E.; Liu, Y.; Shi, X.; Zhang, E.; Shao, L.; Li, A.; Yang, N.; Han, X.; et al. LncRNA H19 confers chemoresistance in ERalpha-positive breast cancer through epigenetic silencing of the pro-apoptotic gene BIK. Oncotarget 2016, 7, 81452-81462. [CrossRef] [PubMed]

117. Vennin, C.; Spruyt, N.; Dahmani, F.; Julien, S.; Bertucci, F.; Finetti, P.; Chassat, T.; Bourette, R.P.; Le Bourhis, X.; Adriaenssens, E. H19 non coding RNA-derived miR-675 enhances tumorigenesis and metastasis of breast cancer cells by downregulating c-Cbl and Cbl-b. Oncotarget 2015, 6, 29209-29223. [CrossRef] [PubMed]

118. Zhang, K.; Luo, Z.; Zhang, Y.; Zhang, L.; Wu, L.; Liu, L.; Yang, J.; Song, X.; Liu, J. Circulating lncRNA H19 in plasma as a novel biomarker for breast cancer. Cancer Biomark. 2016, 17, 187-194. [CrossRef] [PubMed]

119. Jiang, Y.-Z.; Liu, Y.-R.; Xu, X.-E.; Jin, X.; Hu, X.; Yu, K.-D.; Shao, Z.-M. Transcriptome analysis of triple-negative breast cancer reveals an integrated mRNA-lncRNA signature with predictive and prognostic value. Cancer Res. 2016, 76, 2105-2114. [CrossRef] [PubMed] 
120. Liu, M.; Xing, L.-Q.; Liu, Y.-J. A three-long noncoding RNA signature as a diagnostic biomarker for differentiating between triple-negative and non-triple-negative breast cancers. Medicine 2017, 96, e6222. [CrossRef] [PubMed]

121. Liu, W.; Ma, J.; Cheng, Y.; Zhang, H.; Luo, W.; Zhang, H. HMMR antisense RNA 1, a novel long noncoding RNA, regulates the progression of basal-like breast cancer cells. Breast Cancer 2016, 8, 223-229. [CrossRef] [PubMed]

122. Bhan, A.; Hussain, I.; Ansari, K.I.; Kasiri, S.; Bashyal, A.; Mandal, S.S. Antisense transcript long noncoding RNA (lncRNA) HOTAIR is transcriptionally induced by estradiol. J. Mol. Biol. 2013, 425, 3707-3722. [CrossRef] [PubMed]

123. Gupta, R.A.; Shah, N.; Wang, K.C.; Kim, J.; Horlings, H.M.; Wong, D.J.; Tsai, M.-C.; Hung, T.; Argani, P.; Rinn, J.L.; et al. Long non-coding RNA HOTAIR reprograms chromatin state to promote cancer metastasis. Nature 2010, 464, 1071-1076. [CrossRef] [PubMed]

124. Kogo, R.; Shimamura, T.; Mimori, K.; Kawahara, K.; Imoto, S.; Sudo, T.; Tanaka, F.; Shibata, K.; Suzuki, A.; Komune, S.; et al. Long noncoding RNA HOTAIR regulates polycomb-dependent chromatin modification and is associated with poor prognosis in colorectal cancers. Cancer Res. 2011, 71, 6320-6326. [CrossRef] [PubMed]

125. Yoon, J.-H.; Abdelmohsen, K.; Kim, J.; Yang, X.; Martindale, J.L.; Tominaga-Yamanaka, K.; White, E.J.; Orjalo, A.V.; Rinn, J.L.; Kreft, S.G.; et al. Scaffold function of long non-coding RNA HOTAIR in protein ubiquitination. Nat. Commun. 2013, 4, 2939. [CrossRef] [PubMed]

126. Zhang, K.-J.; Zhang, Y.; Luo, Z.-L.; Liu, L.; Yang, J.; Wu, L.-C.; Yu, S.-S.; Liu, J.-B. Long non-coding RNA HOTAIR in plasma as a potential biomarker for breast cancer diagnosis. Nan Fang Yi Ke Da Xue Xue Bao 2016, 36, 488-492. [PubMed]

127. Ozes, A.R.; Wang, Y.; Zong, X.; Fang, F.; Pilrose, J.; Nephew, K.P. Therapeutic targeting using tumor specific peptides inhibits long non-coding RNA HOTAIR activity in ovarian and breast cancer. Sci. Rep. 2017, 7, 894. [CrossRef] [PubMed]

128. Wang, X.Q.D.; Dostie, J. Reciprocal regulation of chromatin state and architecture by HOTAIRM1 contributes to temporal collinear HOXA gene activation. Nucleic Acids Res. 2017, 45, 1091-1104. [CrossRef] [PubMed]

129. Su, X.; Malouf, G.G.; Chen, Y.; Zhang, J.; Yao, H.; Valero, V.; Weinstein, J.N.; Spano, J.-P.; Meric-Bernstam, F.; Khayat, D.; et al. Comprehensive analysis of long non-coding RNAs in human breast cancer clinical subtypes. Oncotarget 2014, 5, 9864-9876. [CrossRef] [PubMed]

130. Fang, Y.; Wang, J.; Wu, F.; Song, Y.; Zhao, S.; Zhang, Q. Long non-coding RNA HOXA-AS2 promotes proliferation and invasion of breast cancer by acting as a miR-520c-3p sponge. Oncotarget 2017, 8, 46090-46103. [CrossRef] [PubMed]

131. Li, W.; Jia, G.; Qu, Y.; Du, Q.; Liu, B.; Liu, B. Long Non-Coding RNA (LncRNA) HOXA11-AS Promotes Breast Cancer Invasion and Metastasis by Regulating Epithelial-Mesenchymal Transition. Med. Sci. Monit. 2017, 23, 3393-3403. [CrossRef] [PubMed]

132. Li, W.-X.; Sha, R.-L.; Bao, J.-Q.; Luan, W.; Su, R.-L.; Sun, S.-R. Expression of long non-coding RNA linc-ITGB1 in breast cancer and its influence on prognosis and survival. Eur. Rev. Med. Pharmacol. Sci. 2017, 21, 3397-3401. [PubMed]

133. Yan, M.; Zhang, L.; Li, G.; Xiao, S.; Dai, J.; Cen, X. Long noncoding RNA linc-ITGB1 promotes cell migration and invasion in human breast cancer. Biotechnol. Appl. Biochem. 2017, 64, 5-13. [CrossRef] [PubMed]

134. Pan, Y.; Li, C.; Chen, J.; Zhang, K.; Chu, X.; Wang, R.; Chen, L. The Emerging Roles of Long Noncoding RNA ROR (lincRNA-ROR) and its Possible Mechanisms in Human Cancers. Cell. Physiol. Biochem. 2016, 40, 219-229. [CrossRef] [PubMed]

135. Shen, Y.; Katsaros, D.; Loo, L.W.M.; Hernandez, B.Y.; Chong, C.; Canuto, E.M.; Biglia, N.; Lu, L.; Risch, H.; $\mathrm{Chu}, \mathrm{W} . \mathrm{M}$.; et al. Prognostic and predictive values of long non-coding RNA LINC00472 in breast cancer. Oncotarget 2015, 6, 8579-8592. [CrossRef] [PubMed]

136. Shen, Y.; Wang, Z.; Loo, L.W.M.; Ni, Y.; Jia, W.; Fei, P.; Risch, H.A.; Katsaros, D.; Yu, H. LINC00472 expression is regulated by promoter methylation and associated with disease-free survival in patients with grade 2 breast cancer. Breast Cancer Res. Treat. 2015, 154, 473-482. [CrossRef] [PubMed]

137. Silva, J.M.; Boczek, N.J.; Berres, M.W.; Ma, X.; Smith, D.I. LSINCT5 is over expressed in breast and ovarian cancer and affects cellular proliferation. RNA Biol. 2011, 8, 496-505. [CrossRef] [PubMed] 
138. Jadaliha, M.; Zong, X.; Malakar, P.; Ray, T.; Singh, D.K.; Freier, S.M.; Jensen, T.; Prasanth, S.G.; Karni, R.; Ray, P.S.; et al. Functional and prognostic significance of long non-coding RNA MALAT1 as a metastasis driver in ER negative lymph node negative breast cancer. Oncotarget 2016, 7, 40418-40436. [CrossRef] [PubMed]

139. Gutschner, T.; Hammerle, M.; Diederichs, S. MALAT1-A paradigm for long noncoding RNA function in cancer. J. Mol. Med. 2013, 91, 791-801. [CrossRef] [PubMed]

140. Huang, N.-S.; Chi, Y.-Y.; Xue, J.-Y.; Liu, M.-Y.; Huang, S.; Mo, M.; Zhou, S.-L.; Wu, J. Long non-coding RNA metastasis associated in lung adenocarcinoma transcript 1 (MALAT1) interacts with estrogen receptor and predicted poor survival in breast cancer. Oncotarget 2016, 7, 37957-37965. [CrossRef] [PubMed]

141. Miao, Y.; Fan, R.; Chen, L.; Qian, H. Clinical Significance of Long Non-coding RNA MALAT1 Expression in Tissue and Serum of Breast Cancer. Ann. Clin. Lab. Sci. 2016, 46, 418-424. [PubMed]

142. Zhang, W.; Shi, S.; Jiang, J.; Li, X.; Lu, H.; Ren, F. LncRNA MEG3 inhibits cell epithelial-mesenchymal transition by sponging miR-421 targeting E-cadherin in breast cancer. Biomed. Pharmacother. 2017, 91, 312-319. [CrossRef] [PubMed]

143. Mondal, T.; Subhash, S.; Vaid, R.; Enroth, S.; Uday, S.; Reinius, B.; Mitra, S.; Mohammed, A.; James, A.R.; Hoberg, E.; et al. MEG3 long noncoding RNA regulates the TGF- $\beta$ pathway genes through formation of RNA-DNA triplex structures. Nat. Commun. 2015, 6, 7743. [CrossRef] [PubMed]

144. Nie, F.-Q.; Ma, S.; Xie, M.; Liu, Y.-W.; De, W.; Liu, X.-H. Decreased long noncoding RNA MIR31HG is correlated with poor prognosis and contributes to cell proliferation in gastric cancer. Tumour. Biol. 2016, 37, 7693-7701. [CrossRef] [PubMed]

145. Augoff, K.; McCue, B.; Plow, E.F.; Sossey-Alaoui, K. miR-31 and its host gene lncRNA LOC554202 are regulated by promoter hypermethylation in triple-negative breast cancer. Mol. Cancer 2012, 11, 5. [CrossRef] [PubMed]

146. Ding, J.; Lu, B.; Wang, J.; Wang, J.; Shi, Y.; Lian, Y.; Zhu, Y.; Wang, J.; Fan, Y.; Wang, Z.; et al. Long non-coding RNA Loc554202 induces apoptosis in colorectal cancer cells via the caspase cleavage cascades. J. Exp. Clin. Cancer Res. 2015, 34, 100. [CrossRef] [PubMed]

147. Li, W.; Zhang, Z.; Liu, X.; Cheng, X.; Zhang, Y.; Han, X.; Zhang, Y.; Liu, S.; Yang, J.; Xu, B.; et al. The FOXN3-NEAT1-SIN3A repressor complex promotes progression of hormonally responsive breast cancer. J. Clin. Investig. 2017, 127, 3421-3440. [CrossRef] [PubMed]

148. Zhang, M.; Wu, W.-B.; Wang, Z.-W.; Wang, X.-H. lncRNA NEAT1 is closely related with progression of breast cancer via promoting proliferation and EMT. Eur. Rev. Med. Pharmacol. Sci. 2017, 21, 1020-1026. [PubMed]

149. Hirose, T.; Virnicchi, G.; Tanigawa, A.; Naganuma, T.; Li, R.; Kimura, H.; Yokoi, T.; Nakagawa, S.; Benard, M.; Fox, A.H.; et al. NEAT1 long noncoding RNA regulates transcription via protein sequestration within subnuclear bodies. Mol. Biol. Cell 2014, 25, 169-183. [CrossRef] [PubMed]

150. Qian, K.; Liu, G.; Tang, Z.; Hu, Y.; Fang, Y.; Chen, Z.; Xu, X. The long non-coding RNA NEAT1 interacted with miR-101 modulates breast cancer growth by targeting EZH2. Arch. Biochem. Biophys. 2017, 615, 1-9. [CrossRef] [PubMed]

151. Jiang, L.; Shao, C.; Wu, Q.-J.; Chen, G.; Zhou, J.; Yang, B.; Li, H.; Gou, L.-T.; Zhang, Y.; Wang, Y.; et al. NEAT1 scaffolds RNA-binding proteins and the Microprocessor to globally enhance pri-miRNA processing. Nat. Struct. Mol. Biol. 2017. [CrossRef] [PubMed]

152. Ke, H.; Zhao, L.; Feng, X.; Xu, H.; Zou, L.; Yang, Q.; Su, X.; Peng, L.; Jiao, B. NEAT1 is Required for Survival of Breast Cancer Cells Through FUS and miR-548. Gene Regul. Syst. Biol. 2016, 10, 11-17. [CrossRef] [PubMed]

153. Iranpour, M.; Soudyab, M.; Geranpayeh, L.; Mirfakhraie, R.; Azargashb, E.; Movafagh, A.; Ghafouri-Fard, S. Expression analysis of four long noncoding RNAs in breast cancer. Tumour. Biol. 2016, 37, 2933-2940. [CrossRef] [PubMed]

154. Zhao, W.; Luo, J.; Jiao, S. Comprehensive characterization of cancer subtype associated long non-coding RNAs and their clinical implications. Sci. Rep. 2014, 4, 6591. [CrossRef] [PubMed]

155. Colombo, T.; Farina, L.; Macino, G.; Paci, P. PVT1: A rising star among oncogenic long noncoding RNAs. BioMed Res. Int. 2015, 2015, 304208. [CrossRef] [PubMed]

156. Tseng, Y.-Y.; Bagchi, A. The PVT1-MYC duet in cancer. Mol. Cell. Oncol. 2015, 2, e974467. [CrossRef] [PubMed]

157. Sarver, A.L.; Murray, C.D.; Temiz, N.A.; Tseng, Y.-Y.; Bagchi, A. MYC and PVT1 synergize to regulate RSPO1 levels in breast cancer. Cell Cycle 2016, 15, 881-885. [CrossRef] [PubMed] 
158. Tseng, Y.-Y.; Moriarity, B.S.; Gong, W.; Akiyama, R.; Tiwari, A.; Kawakami, H.; Ronning, P.; Reuland, B.; Guenther, K.; Beadnell, T.C.; et al. PVT1 dependence in cancer with MYC copy-number increase. Nature 2014, 512, 82-86. [CrossRef] [PubMed]

159. Shahryari, A.; Jazi, M.S.; Samaei, N.M.; Mowla, S.J. Long non-coding RNA SOX2OT: Expression signature, splicing patterns, and emerging roles in pluripotency and tumorigenesis. Front. Genet. 2015, 6, 196. [CrossRef] [PubMed]

160. Askarian-Amiri, M.E.; Seyfoddin, V.; Smart, C.E.; Wang, J.; Kim, J.E.; Hansji, H.; Baguley, B.C.; Finlay, G.J.; Leung, E.Y. Emerging role of long non-coding RNA SOX2OT in SOX2 regulation in breast cancer. PLoS ONE 2014, 9, e102140. [CrossRef] [PubMed]

161. Shi, Y.; Li, J.; Liu, Y.; Ding, J.; Fan, Y.; Tian, Y.; Wang, L.; Lian, Y.; Wang, K.; Shu, Y. The long noncoding RNA SPRY4-IT1 increases the proliferation of human breast cancer cells by upregulating ZNF703 expression. Mol. Cancer 2015, 14, 51. [CrossRef] [PubMed]

162. Li, J.; Chen, Y.; Chen, Z.; He, A.; Xie, H.; Zhang, Q.; Cai, Z.; Liu, Y.; Huang, W. SPRY4-IT1: A novel oncogenic long non-coding RNA in human cancers. Tumour. Biol. 2017, 39, 1010428317711406. [CrossRef] [PubMed]

163. Cusanelli, E.; Chartrand, P. Telomeric repeat-containing RNA TERRA: A noncoding RNA connecting telomere biology to genome integrity. Front. Genet. 2015, 6, 143. [CrossRef] [PubMed]

164. Azzalin, C.M.; Reichenbach, P.; Khoriauli, L.; Giulotto, E.; Lingner, J. Telomeric repeat containing RNA and RNA surveillance factors at mammalian chromosome ends. Science 2007, 318, 798-801. [CrossRef] [PubMed]

165. Luke, B.; Lingner, J. TERRA: Telomeric repeat-containing RNA. EMBO J. 2009, 28, 2503-2510. [CrossRef] [PubMed]

166. Deng, Z.; Norseen, J.; Wiedmer, A.; Riethman, H.; Lieberman, P.M. TERRA RNA binding to TRF2 facilitates heterochromatin formation and ORC recruitment at telomeres. Mol. Cell 2009, 35, 403-413. [CrossRef] [PubMed]

167. Yao, J.; Xu, F.; Zhang, D.; Yi, W.; Chen, X.; Chen, G.; Zhou, E. TP73-AS1 promotes breast cancer cell proliferation through miR-200a-mediated TFAM inhibition. J. Cell. Biochem. 2017. [CrossRef] [PubMed]

168. Gumireddy, K.; Li, A.; Yan, J.; Setoyama, T.; Johannes, G.J.; Orom, U.A.; Tchou, J.; Liu, Q.; Zhang, L.; Speicher, D.W.; et al. Identification of a long non-coding RNA-associated RNP complex regulating metastasis at the translational step. EMBO J. 2013, 32, 2672-2684. [CrossRef] [PubMed]

169. Huang, J.; Zhou, N.; Watabe, K.; Lu, Z.; Wu, F.; Xu, M.; Mo, Y.-Y. Long non-coding RNA UCA1 promotes breast tumor growth by suppression of p27 (Kip1). Cell Death Dis. 2014, 5, e1008. [CrossRef] [PubMed]

170. Tuo, Y.-L.; Li, X.-M.; Luo, J. Long noncoding RNA UCA1 modulates breast cancer cell growth and apoptosis through decreasing tumor suppressive miR-143. Eur. Rev. Med. Pharmacol. Sci. 2015, 19, 3403-3411. [PubMed]

171. Xiao, C.; Wu, C.-H.; Hu, H.-Z. LncRNA UCA1 promotes epithelial-mesenchymal transition (EMT) of breast cancer cells via enhancing Wnt/beta-catenin signaling pathway. Eur. Rev. Med. Pharmacol. Sci. 2016, 20, 2819-2824. [PubMed]

172. Li, X.; Wu, Y.; Liu, A.; Tang, X. Long non-coding RNA UCA1 enhances tamoxifen resistance in breast cancer cells through a miR-18a-HIF1alpha feedback regulatory loop. Tumour. Biol. 2016, 37, 14733-14743. [CrossRef] [PubMed]

173. Wu, C.; Luo, J. Long Non-Coding RNA (lncRNA) Urothelial Carcinoma-Associated 1 (UCA1) Enhances Tamoxifen Resistance in Breast Cancer Cells via Inhibiting mTOR Signaling Pathway. Med. Sci. Monit. 2016, 22, 3860-3867. [CrossRef] [PubMed]

174. Tian, F.-M.; Meng, F.-Q.; Wang, X.-B. Overexpression of long-noncoding RNA ZFAS1 decreases survival in human NSCLC patients. Eur. Rev. Med. Pharmacol. Sci. 2016, 20, 5126-5131. [PubMed]

175. Askarian-Amiri, M.E.; Crawford, J.; French, J.D.; Smart, C.E.; Smith, M.A.; Clark, M.B.; Ru, K.; Mercer, T.R.; Thompson, E.R.; Lakhani, S.R.; et al. SNORD-host RNA Zfas1 is a regulator of mammary development and a potential marker for breast cancer. RNA 2011, 17, 878-891. [CrossRef] [PubMed]

176. Wang, W.; Xing, C. Upregulation of long noncoding RNA ZFAS1 predicts poor prognosis and prompts invasion and metastasis in colorectal cancer. Pathol. Res. Pract. 2016, 212, 690-695. [CrossRef] [PubMed]

177. Zhou, H.; Wang, F.; Chen, H.; Tan, Q.; Qiu, S.; Chen, S.; Jing, W.; Yu, M.; Liang, C.; Ye, S.; et al. Increased expression of long-noncoding RNA ZFAS1 is associated with epithelial-mesenchymal transition of gastric cancer. Aging 2016, 8, 2023-2038. [CrossRef] [PubMed] 
178. Hansji, H.; Leung, E.Y.; Baguley, B.C.; Finlay, G.J.; Cameron-Smith, D.; Figueiredo, V.C.; Askarian-Amiri, M.E. ZFAS1: A long noncoding RNA associated with ribosomes in breast cancer cells. Biol. Direct 2016, 11, 62. [CrossRef] [PubMed]

179. Paik, S.; Shak, S.; Tang, G.; Kim, C.; Baker, J.; Cronin, M.; Baehner, F.L.; Walker, M.G.; Watson, D.; Park, T.; et al. A multigene assay to predict recurrence of tamoxifen-treated, node-negative breast cancer. N. Engl. J. Med. 2004, 351, 2817-2826. [CrossRef] [PubMed]

180. Gnant, M.; Sestak, I.; Filipits, M.; Dowsett, M.; Balic, M.; Lopez-Knowles, E.; Greil, R.; Dubsky, P.; Stoeger, H.; Rudas, M.; et al. Identifying clinically relevant prognostic subgroups of postmenopausal women with node-positive hormone receptor-positive early-stage breast cancer treated with endocrine therapy: A combined analysis of ABCSG-8 and ATAC using the PAM50 risk of recurrence. Ann. Oncol. Off. J. Eur. Soc. Med. Oncol. 2015, 26, 1685-1691. [CrossRef] [PubMed]

181. Mook, S.; Schmidt, M.K.; Viale, G.; Pruneri, G.; Eekhout, I.; Floore, A.; Glas, A.M.; Bogaerts, J.; Cardoso, F.; Piccart-Gebhart, M.J.; et al. The 70-gene prognosis-signature predicts disease outcome in breast cancer patients with 1-3 positive lymph nodes in an independent validation study. Breast Cancer Res. Treat. 2009, 116, 295-302. [CrossRef] [PubMed]

182. Guo, W.; Wang, Q.; Zhan, Y.; Chen, X.; Yu, Q.; Zhang, J.; Wang, Y.; Xu, X.-J.; Zhu, L. Transcriptome sequencing uncovers a three-long noncoding RNA signature in predicting breast cancer survival. Sci. Rep. 2016, 6, 27931. [CrossRef] [PubMed]

183. Zhou, M.; Zhong, L.; Xu, W.; Sun, Y.; Zhang, Z.; Zhao, H.; Yang, L.; Sun, J. Discovery of potential prognostic long non-coding RNA biomarkers for predicting the risk of tumor recurrence of breast cancer patients. Sci. Rep. 2016, 6, 31038. [CrossRef] [PubMed]

184. Liu, H.; Li, J.; Koirala, P.; Ding, X.; Chen, B.; Wang, Y.; Wang, Z.; Wang, C.; Zhang, X.; Mo, Y.-Y. Long non-coding RNAs as prognostic markers in human breast cancer. Oncotarget 2016, 7, 20584-20596. [CrossRef] [PubMed]

185. Liu, Y.-R.; Jiang, Y.-Z.; Xu, X.-E.; Hu, X.; Yu, K.-D.; Shao, Z.-M. Comprehensive Transcriptome Profiling Reveals Multigene Signatures in Triple-Negative Breast Cancer. Clin. Cancer Res. 2016, 22, 1653-1662. [CrossRef] [PubMed]

186. Wahlestedt, C. Targeting long non-coding RNA to therapeutically upregulate gene expression. Nat. Rev. Drug Discov. 2013, 12, 433-446. [CrossRef] [PubMed]

187. MacLeod, A.R.; Crooke, S.T. RNA Therapeutics in Oncology: Advances, Challenges, and Future Directions. J. Clin. Pharmacol. 2017, 57, S43-S59. [CrossRef] [PubMed]

188. Modarresi, F.; Faghihi, M.A.; Lopez-Toledano, M.A.; Fatemi, R.P.; Magistri, M.; Brothers, S.P.; van der Brug, M.P.; Wahlestedt, C. Inhibition of natural antisense transcripts in vivo results in gene-specific transcriptional upregulation. Nat. Biotechnol. 2012, 30, 453-459. [CrossRef] [PubMed] 